\title{
AN EVALUATION OF MATERIALS OF CONSTRUCTION FOR THE SULFLEX AND ZIRFLEX PROCESSES
}

\author{
HERBERT KATZ AND ROBERT ISLER
}

Approved by:

B. MANOWITZ
Work done by:

H. KATZ R. MOGK

R. ISLER C. BREWSTER

T. SCHREINER

August 1962

BROOKHAVEN NATIONAL LABORATORY UPTON, NEW YORK 


\section{DISCLAIMER}

This report was prepared as an account of work sponsored by an agency of the United States Government. Neither the United States Government nor any agency Thereof, nor any of their employees, makes any warranty, express or implied, or assumes any legal liability or responsibility for the accuracy, completeness, or usefulness of any information, apparatus, product, or process disclosed, or represents that its use would not infringe privately owned rights. Reference herein to any specific commercial product, process, or service by trade name, trademark, manufacturer, or otherwise does not necessarily constitute or imply its endorsement, recommendation, or favoring by the United States Government or any agency thereof. The views and opinions of authors expressed herein do not necessarily state or reflect those of the United States Government or any agency thereof. 


\section{DISCLAIMER}

Portions of this document may be illegible in electronic image products. Images are produced from the best available original document. 
LEGAL NOTICE

This report was prepared as an account of Government sponsored work. Neither the United States. nor the Commission, nor any person acting on behalf of the Commission:

A. Makes any warranty or representation. expressed or implied, with respect to the accuracy, completeness, or usefulness of the information contained in this report, or that the use of any information, apparatus, method, or process disclosed in this report may not infringe privately owned rights: or

B. Assumes any liabilities with respect to the use of, or for damages resulting from the use of any information, apparatus, method, or precess disclosed in this report.

As used in the above, "person acting on behalf of the (inmmission" includes any employee or contractor of the Commission, or mploy ere of unch contractor, to the extent that such emplovee or contractor of the Commission, or emplox ee of such contractor prepares, disseminates, or provides access to, any information puruant to his employment or contract with the Commission. or his emplownent with such contrat tor.

\section{PRINTED IN (SA}

\section{PRICE $\$ 1.25$}

Available from the office of Technical Services

Departinent of Commeret Washington 25, D.C. 


\section{Abstract}

The corrosion resistance of a number of potential materials of construction for both the sulfex and zirflex processes has been studied. The results indicate that Ni-o-nel is a satisfactory material for the sulfex process provided the sulfuric acid concentration is not greater than four molar, and the nitric acid concentration is not greater than five molar. In addition, core dissolutions should be done below the boiling point, and heat transfer surface temperatures during core dissolution should be maintained below $240^{\circ} \mathrm{F}$. Carpenter $20 \mathrm{Cb}$ is probably less satisfactory for sulfex service because of selective weld attack. Neither Ni-o-nel, $309 \mathrm{sCb}$ or $304 \mathrm{~L}$ is a satisfactory construction material for uninhibited zirflex solutions. Cupric ion lowers the corrosion rate of $309 \mathrm{scb}$ to $30-40$ mils per year, but is not a satisfactory inhibitor for 304I or Ni-o-nel. 
-

- 


\section{Table of contents}

I

II

III

IV

$\mathrm{V}$
2

Procedures

5

A. Corrosion in 3 and $4 \mathrm{M} \mathrm{H}_{2} \mathrm{SO}_{4}$

1. Wrought Ni-o-nel 5

2. Welded Ni-O-nel 10

B. Corrosion in $6 \mathrm{M}_{2} \mathrm{H}_{2} \mathrm{SO}_{4} \quad 13$

c. Corrosion of Heat Transfer Surfaces

Ni-o-ne1-Nitric Acid

A. Isothermal Tests 18

B. Heat Transfer Tests 24

Carpenter 20-Sulfex 26

A. Sulfuric Acid Tests 26

B. Nitric Acid Tests 26

Zirflex Corrosion studies $\quad 29$

A. $309 \mathrm{scb} 29$

B. $304 \mathrm{~L} \quad 30$

C. Ni-o-nel 33

Summary \& Conclusions $\quad 35$

References $\quad 36$

$\begin{array}{ll}\text { Figures } & 37\end{array}$ 


\section{AN EVALUATION OF MATERIALS OF CONSTRUCTION}

FOR THE SULFEX AND ZIRFLEX PROCESSES

Many of the civilian power reactors in operation or under construction utilize fuel elements consisting of $\mathrm{vO}_{2}$ clad in alloys of high corrosion resistance, such as stainless steel or zircalloy. The preparation of these fuels for chemical reprocessing by solvent extraction techniques, therefore, requires the use of highly corrosive solutions to dissolve the cladding, and thus presents some problems in finding a suitable material of construction for the dissolver vessel.

One of the processes which has been developed for dissolution of stainless steel clad oxide fuels is the sulfex process (1)(2). This process consists of chemical decladding in $4-6 \mathrm{M}_{2} \mathrm{H}_{2} \mathrm{SO}_{4}$, removal of the decladding solution, followed by dissolution of the oxide core in nitric acid. The zirflex process (3) (4), developed for the dissolution of zircalloy clad fuels, consists of decladding in $6 \underline{\mathrm{M}} \mathrm{NH}_{4} \mathrm{~F}-0.5 \mathrm{M}_{4} \mathrm{NH}_{4} \mathrm{NO}_{3}$, also followed by removal of the decladding solution and dissolution of the oxide core in nitric acid.

Although some corrosion data is available for potential materials of construction for both these processes, there are some important gaps and areas of disagreement in the existing data, and it is sometimes difficult to compare the work of different investigators because of differences in test procedures or lack of information on the procedures used. This report describes the results of a series of 
corrosion tests on $\mathrm{Ni}-0-n e l$ and carpenter $20 \mathrm{Cb}$ in sulfex solutions, and Ni-o-nel. $304-\mathrm{I}$ and $309 \mathrm{sCb}$ stainless steel in Zirflex solutions. Tests in sulfex solutions. particularly with $\mathrm{Ni-o-nel,} \mathrm{were} \mathrm{extensive,}$ and it is felt that all the information which can be obtained from laboratory data is now available for evaluating this system. Tests in zirflex solutions were of a scouting nature to see whether suitable corrosion inhibitors could be found to allow the use of a stainless steel dissolver for this process.

\section{Description of Materials and Test Procedures}

The composition of the alloys studied are shown in Table $I$. Three different heats of Ni-o-nel were used in these studies, but the variations in composition were minor, and there was no difference in corrosion resistance among the three.

All specimens, except the heavy Ni-o-nel weld specimens were cut from 1/4" plate, and were prepared for testing according the the for lowing procedure.

1. Polish with 120 grit emery paper

2. Trichloroethylene vapor degrease

3. Hot dip in trisodium phosphate solution containing $13 \mathrm{~g} / \mathrm{l}$ phosphate and $5 \mathrm{~g} / \mathrm{l}$ Aerosol oT, followed by distilled water rinse.

4. Dip in 5 weight per cent $\mathrm{H}_{2} \mathrm{SO}_{4}$, at room temperature, followed by distilled water rinse.

5. Pickle 10-15 minutes at 50-65 degrees c. in 10 vol. \% $\mathrm{HNO}_{3}$ - I to $2 \mathrm{vol}$. \% HF, followed by distilled water 
TABLE I

Composition of Materials of Construction

\begin{tabular}{|c|c|c|c|c|}
\hline & Ni-o-nel & Carpenter 20 & $309 \mathrm{scb}$ & $304 \mathrm{~L}$ \\
\hline $\mathrm{Ni}$ & 41.63 & 34.74 & $12-15$ & $8-12$ \\
\hline $\mathrm{Cr}$ & 20.90 & 20.13 & $22-24$ & $18-20$ \\
\hline MO & 2.95 & 2.25 & - & - \\
\hline $\mathrm{Cu}$ & 1.69 & 3.25 & - & - \\
\hline $\mathrm{Cb}$ & - & 0.83 & - & - \\
\hline $\mathrm{Ti}$ & 0.85 & - & - & - \\
\hline $\operatorname{Mn}$ & 0.76 & - & 2.00 & 2.00 \\
\hline s & 0.007 & - & - & .030 \\
\hline Si & 0.32 & - & 1.00 & 1.00 \\
\hline Al & 0.09 & - & - & - \\
\hline C & 0.03 & 0.06 & 0.1 & .03 \\
\hline$P$ & & & - & .045 \\
\hline
\end{tabular}


5. rinse.

6. Passivation for 2 minutes in 10 weight $\% \mathrm{HNO}_{3}$ at 65 degrees c., followed by distilled water rinse and drying

7. Weighing and measuring, followed by another degreasing and passivation just prior to use.

The only exceptions to this procedure were that welded specimens were not polished prior to cleaning, and step (5) was omitted in the case of stainless steel specimens.

All isothermal tests, except with zirflex solutions, were run in three neck, 1 liter, round bottom glass flasks, heated with mantles to maintain the solution at the atmospheric boiling point. zirflex tests were run in all Teflon equipment. Unless otherwise stated straight updraft condensers were used, and the solutions were not sparged. Liquid phase specimens were supported in glass baskets and were fully immersed in the liquid phase. Vapor phase specimens were suspended above the solution and were at least partially wetted by condensate. Volumes of solution were varied so as to maintain a ratio of solution volume to metal surface area of about $200 \mathrm{~m} 1$ per square inch. Unless otherwise noted, technical grade reagents were 
used.

Tests were run for multiples of forty-eight hour periods, except for those tests run in the presence of dissolving metal, where the period was determined by the dissolution time. Test specimens were rinsed, dried, and weighed after each test period, and immersed in fresh solution for the next period. In the case of tests with heat transfer surfaces, the solutions were changed every forty-eight hours without removing the test specimen, which were weighed only at the termination of the test.

II. Ni-o-nel - sulfuric Acid

A. Corrosion in 3 and $4 \mathrm{M} \mathrm{H}_{2} \mathrm{SO}_{4}$

1. Wrought $\mathrm{Ni}-\mathrm{O}-\mathrm{nel}$

The first set of runs in $4 \mathrm{M} \mathrm{H}_{2} \mathrm{SO}_{4}$ were made to determine whether there were significant variations in the behavior of Ni-o-nel from heat to heat, and to determine whether there was any difference in corrosion rates in technical grade and C.P. acid. These results are shown in Table II, along with the results of two tests in $3 \mathrm{M}_{2} \mathrm{H}_{2} \mathrm{SO}_{4}$. It is apparent that the corrosion rate in $4 \mathrm{M}_{2} \mathrm{H}_{2} \mathrm{SO}_{4}$ is independent of either the heat of Ni-o-nel or the grade of acid used. For this reason, technical grade acid was used in all subsequent tests in this system. Although the corrosion rate in $3 \mathrm{M} \mathrm{H}_{2} \mathrm{SO}_{4}$ is less than in $4 \mathrm{M}$, no further work was done in $3 \mathrm{M} \mathrm{H}_{2} \mathrm{SO}_{4}$ because of probable difficulty in initiating the dissolution of stainless steel cladding in this low an acid concentration. A typical photomicrograph of 
TABLE II

CORROSION OF WROUGHT NI-O-NEL IN $3-4 \mathrm{M} \mathrm{H}_{2} \mathrm{SO}_{4}$

Corrosion Rate, mils per year

\begin{tabular}{|c|c|c|c|c|c|}
\hline Solution & $\begin{array}{l}\text { Pimesure } \\
\text { Time } \\
\text { Hours }\end{array}$ & Heat $8865 F$. & Heat $9597 \mathrm{~F}$. & Heat $128 \mathrm{~F}$. & \\
\hline \multirow{6}{*}{$\begin{array}{l}\text { Boiling } 4 \frac{\mathrm{M}}{\mathrm{H}_{2} \mathrm{SO}_{4}} \\
\text { Tech Grade }\end{array}$} & 48 & 19.9 & 11.8 & 30.4 & \\
\hline & 96 & 17.1 & 26.1 & 45.3 & \\
\hline & 144 & 26.6 & 12.3 & 15.4 & \\
\hline & 192 & 8.8 & 39.6 & 20.4 & \\
\hline & 240 & 42.0 & LOST & 15.9 & \\
\hline & AVG. & 22.9 & 22.5 & 25.5 & \\
\hline \multirow{6}{*}{$\begin{array}{l}\text { Boiling } 4 \frac{\mathrm{M}}{\mathrm{H}_{2} \mathrm{SO}_{4}} \\
\text { C. P. Grade }\end{array}$} & 48 & 24.3 & 41.4 & 17.8 & \\
\hline & 96 & 26.2 & 19.4 & 15.6 & \\
\hline & 144 & 35.6 & 20.2 & 15.0 & \\
\hline & 192 & 15.3 & 41.7 & 17.7 & \\
\hline & 240 & 16.2 & 19.5 & 15.0 & \\
\hline & AVG. & 23.5 & 28.5 & 16.2 & \\
\hline \multirow{6}{*}{$\begin{array}{l}\text { Boiling } 3 \mathrm{M}_{2} \mathrm{SO}_{4} \\
\text { Tech Grade }\end{array}$} & 48 & & & 18.7 & 15.9 \\
\hline & 96 & & & 14.8 & 13.0 \\
\hline & 144 & & & 13.2 & 13.8 \\
\hline & 192 & & & 11.2 & 11.7 \\
\hline & 240 & & & 13.0 & 11.9 \\
\hline & AVG. & & & 14.2 & 13.2 \\
\hline
\end{tabular}


wrought $\mathrm{Ni}-\mathrm{O}-\mathrm{nel}$ exposed to $4 \mathrm{M}_{2} \mathrm{H}_{2} \mathrm{SO}_{4}$ for 240 hours is shown in Fig. I. Two additional series of tests of wrought $\mathrm{Ni}-\mathrm{O}-\mathrm{nel}$ in $4 \mathrm{M} \mathrm{H}_{2} \mathrm{SO}_{4}$ were run in order to determine the effect of dissolved air on the corrosion rate. In one of these tests, a cold finger condenser with a pop safety vent was used, and in the other a conventional updraft condenser was used and the solution was sparged with air. These results are shown in Table III. The air sparge had essentially no effect on the corrosion, and the use of a cold finger condenser approximately doubled the corrosion rate.

The effect of dissolved stainless steel on the corrosion rate is shown in Table IV. Dissolved 348 or 304 I stainless steel lowered the corrosion rate by a factor of about ten. This effect was independent of the concentration of dissolved stainless steel. in the range of 5 to 50 grams per liter of dissolved steel. The effect of actively dissolving stainless steel was measured in a series of five dissolutions, with times varying from 4.9 to 9.5 hours. The average corrosion rate in these tests was $13.2 \mathrm{mils}$ per year, which is higher than expected in view of the data in Table IV. However, the short time period of the tests with dissolving stainless steel probably makes those data less reliable. Two additional series of tests were run with $4 \mathrm{M} \mathrm{H}_{2} \mathrm{SO}_{4}$ containing 25 grams per liter of dissolved stainless steel, one using a cold finger condenser, and the other with an air sparge. These results checked very closely with those shown in Table IV, showing that the effect of the dissolved stainless steel was 
TABLE III

CORROSION OF WROUGHT NI-O-NEL IN $4 \mathrm{MI} \mathrm{H}_{2} \mathrm{SO}_{4}$ Corrosion Rate, mils per year

\begin{tabular}{lccc} 
Solution & $\begin{array}{c}\text { Exposure } \\
\text { Time } \\
\text { Hours }\end{array}$ & & \\
\hline Boiling $4 \mathrm{M}_{2} \mathrm{SO}_{4}$ & 48 & 37.4 & 35.8 \\
Cold Finger Cond. & 96 & 48.0 & 65.0 \\
& 144 & 25.2 & 50.9 \\
& 192 & 45.6 & 48.5 \\
& 240 & 16.3 & 53.3 \\
& AVG. & 34.5 & 50.7 \\
Boiling 4M $\mathrm{H}_{2}$ SO $_{4}$ & 48 & & \\
LIEBIG Cond. & 96 & 32.1 & 23.8 \\
Constant air & 144 & 32.6 & 23.4 \\
Sparge .9-1.5 1/min. & 192 & 23.4 & 22.2 \\
& 240 & 22.9 & 23.8 \\
& AVG. & 22.4 & 23.7
\end{tabular}


TABLE IV

CORROSION OF WROUGHT NI-O-NEL IN $4 \mathrm{M} \mathrm{H}_{2} \mathrm{SO}_{4}$

PLUS DISSOLVED STAINLESS STEEL

Corrosion Rate, mils per year

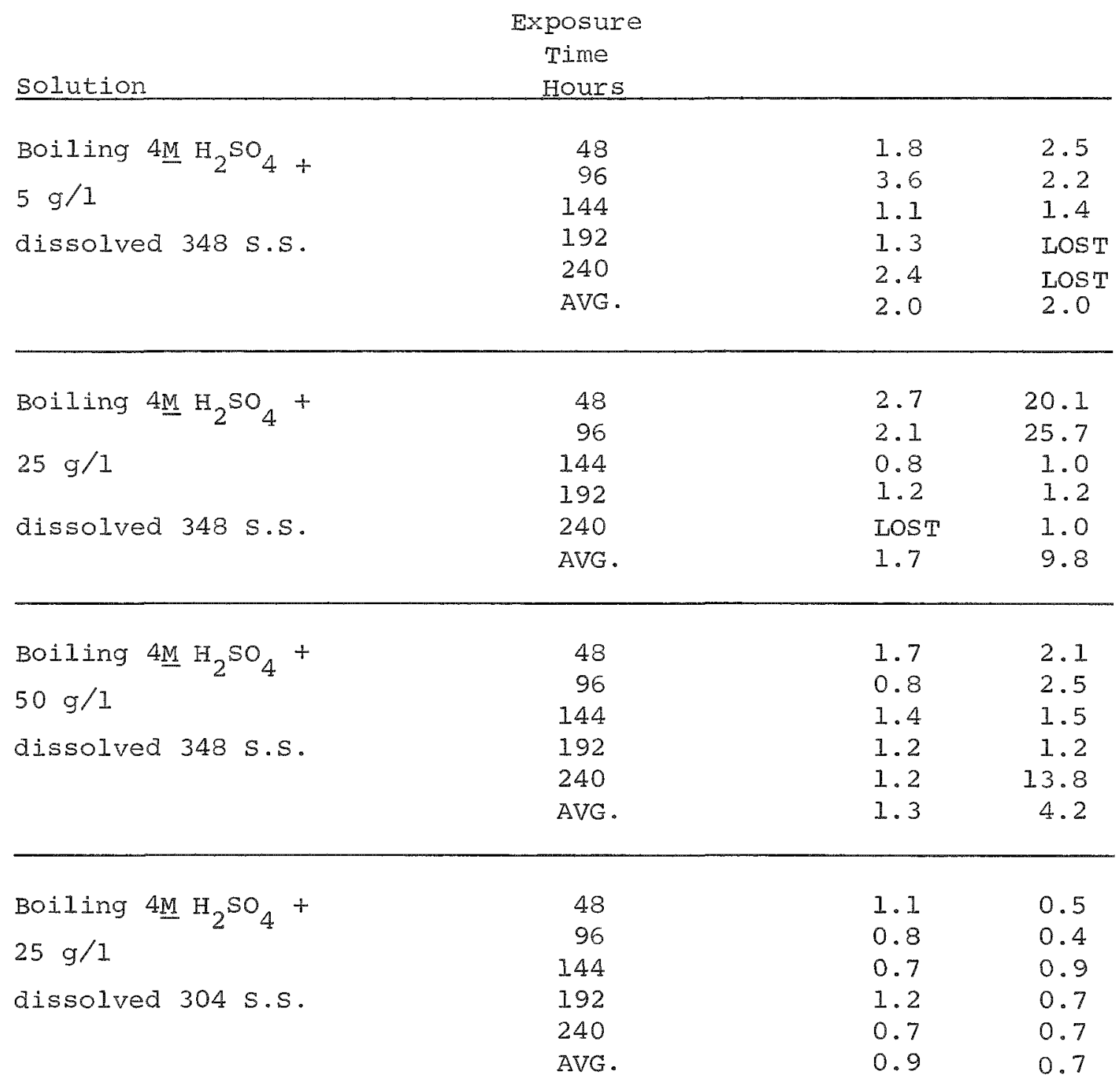


much greater than that due to the use of a cold finger condenser.

\section{Welded $\mathrm{Ni}-\mathrm{O}-\mathrm{nel}$}

For testing of welded Ni-o-nel, both metal arc and inert gas welds were used, and three different sets of specimens were tested with each type of weld. The first set of specimens were one quarter inch plate, which was inert gas welded with 5 to 6 passes of \#65 wire or metal arc welded with 9 passes of \#135 wire. The next set of specimens were one half inch plate, which simulated more closely the welding practices on typical plant dissolver vessels. These specimens were metal arc welded with 9 passes of \#135 wire. Or inert gas welded with 3 passes of \#65 wire and filled in with metal arc welding. Thus in the latter case both metal arc and inert gas welds were exposed to the solution. The third set of specimens were one half inch plate with cross welds, to determine the effect of resensitizing the heat affected zone. For these. a small groove was milled at right angles to the original weld. and filled in with 2 to 3 passes of either metal arc or inert gas welding.

Results of tests with one quarter inch welded plate are shown in Table $\mathrm{V}$ and $\mathrm{VI}$. The data in Table $\mathrm{V}$ indicate that there is no difference in corrosion rate between metal arc and inert gas welds, and that both show rates about one half those observed with wrought specimens. These data also confirm the unvarying behavior of different heats of Ni-o-nel. In Table VI are shown the results of longer term tests with TIG welded specimens in both the liquid and vapor phases. These results generally confirm the results of shorter term tests, and 
TABLE V

CORROSION OF WELDED NI-O-NEL IN $4 \mathrm{M} \mathrm{H}_{2} \mathrm{SO}_{4}$

Corrosion Rate, mils per year

\begin{tabular}{|c|c|c|c|c|c|c|c|}
\hline Solution & $\begin{array}{l}\text { Exposure } \\
\text { Time } \\
\text { Hours } \\
\end{array}$ & Heat $8865 \mathrm{~F}$. & & Heat $9597 \mathrm{~F}$. & & Heat $128 \mathrm{~F}$. & \\
\hline \multirow{6}{*}{$\begin{array}{l}\text { Boiling } 4 \mathrm{M}_{2} \mathrm{SO}_{4} \\
\text { Metal Arc Weld } \\
135 \text { Wire }\end{array}$} & 48 & 20.2 & 12.4 & 14.0 & 14.2 & 9.6 & 17.9 \\
\hline & 96 & 13.0 & 13.0 & 12.5 & 13.4 & 11.3 & 15.0 \\
\hline & 144 & 12.6 & 12.7 & 13.3 & 12.9 & 4.0 & 6.2 \\
\hline & 192 & 25.8 & 12.4 & 13.2 & 19.1 & 6.0 & 7.2 \\
\hline & 240 & 15.6 & 11.9 & 14.9 & 14.2 & 17.6 & 16.5 \\
\hline & AVG. & 17.4 & 12.5 & 13.5 & 14.8 & 9.7 & 12.5 \\
\hline \multirow{3}{*}{$\begin{array}{l}\text { Boiling } 4 \mathrm{M} \mathrm{H}_{2} \mathrm{SO}_{4} \\
\text { TIG Weld }\end{array}$} & 48 & 15.0 & 20.8 & 21.5 & 22.6 & 27.5 & 17.8 \\
\hline & 96 & 11.2 & 16.5 & 16.4 & 17.0 & 16.0 & 14.2 \\
\hline & 144 & 9.7 & 12.6 & 6.7 & 12.9 & 13.2 & 8.5 \\
\hline \multirow[t]{2}{*}{65 Wire } & 192 & 14.7 & 17.3 & 8.2 & 16.2 & 13.8 & 9.6 \\
\hline & 240 & 14.0 & 11.8 & 19.6 & 15.7 & 13.5 & 19.5 \\
\hline - & AVG. & 12.9 & 15.8 & 14.4 & 16.9 & 16.8 & 13.9 \\
\hline
\end{tabular}


TABLE VI

CORROSION OF WELDED NI-O-NEL IN $4 \mathrm{MI} \mathrm{H}_{2} \mathrm{SO}_{4}$ Corrosion Rate, mils per year

\begin{tabular}{|c|c|c|c|c|c|}
\hline \multirow[b]{2}{*}{ Solution } & \multirow{2}{*}{$\begin{array}{l}\text { Exposure } \\
\text { Time } \\
\text { Hours } \\
\end{array}$} & \multicolumn{2}{|c|}{ Heat $128 \mathrm{~F}$} & \multicolumn{2}{|c|}{ Heat 9597} \\
\hline & & Liguid & Vapor & Iiquid & Vapor \\
\hline \multirow{18}{*}{$\begin{array}{l}\text { Boiling } 4 \mathrm{M}_{2} \mathrm{SO}_{4} \\
\text { TIG Weld }\end{array}$} & 48 & 21.6 & 16.1 & 33.1 & 8.4 \\
\hline & 96 & 21.6 & 6.9 & 29.7 & 8.3 \\
\hline & 144 & 7.5 & 11.7 & 20.8 & 10.5 \\
\hline & 192 & 7.5 & 11.9 & 20.2 & 9.4 \\
\hline & 240 & 6.1 & 10.0 & 16.4 & 10.1 \\
\hline & 288 & 0.6 & 0.9 & 7.0 & 9.5 \\
\hline & 336 & 2.4 & 13.2 & 12.2 & 13.3 \\
\hline & 384 & 0.8 & 0.7 & 7.1 & 10.9 \\
\hline & 432 & 0.7 & 10.2 & 15.4 & 12.5 \\
\hline & 480 & 13.9 & 7.6 & 7.9 & 8.7 \\
\hline & 528 & 10.2 & 10.5 & 15.8 & 1.2 \\
\hline & 576 & 14.7 & 11.6 & 0.8 & 2.1 \\
\hline & 624 & 1.2 & 1.4 & 15.6 & 1.5 \\
\hline & 672 & 15.8 & 12.1 & 11.8 & 15.3 \\
\hline & 720 & & & 12.5 & 13.0 \\
\hline & 768 & & & 11.8 & 10.8 \\
\hline & 816 & & & 12.2 & 10.5 \\
\hline & AVG. & 8.9 & 8.9 & 14.8 & 9.2 \\
\hline \multirow{6}{*}{$\begin{array}{l}\text { Boiling } 4 \mathrm{M} \mathrm{H}_{2} \mathrm{SO}_{4} \\
\text { TIG Weld }\end{array}$} & 48 & 46.6 & 21.2 & & \\
\hline & 96 & 11.8 & 18.2 & & \\
\hline & 144 & 13.9 & 17.3 & & \\
\hline & 192 & 16.0 & 37.6 & & \\
\hline & 240 & 16.6 & 22.2 & & \\
\hline & AVG. & 21.0 & 23.3 & & \\
\hline
\end{tabular}


indicate that vapor phase corrosion rates are about the same as those in the liquid phase.

Results of tests with one half inch welded plate are shown in Tables VII and VIII. The heavier welded plate, with either single or cross welds, inert gas or metal arc, shows essentially the same corrosion rate as the thinner plate.

The effect of dissolved stainless steel on corrosion welded specimens is shown in Table IX. The effect of dissolved stainless steel is smaller with welded than with wrought specimens, lowering the corrosion rate by only a factor of two to three. Similar results were obtained on duplicate runs with cross welded specimens, with both metal arc and inert gas welds.

Photomicrographs of welded $\mathrm{Ni}-\mathrm{O}-\mathrm{nel}$ exposed to $4 \mathrm{M}_{2} \mathrm{H}_{2} \mathrm{SO}_{4}$ and $4 \mathrm{M}_{2} \mathrm{HO}_{4}$ plus dissolved stainless steel for 240 hour periods are shown in Figs. 2, 3, \& 4 .

B. Corrosion in 6M Sulfuric Acid

Initial tests with $6 \mathrm{M}$ sulfuric acid were run for 240 hour periods and showed liquid phase corrosion rates of 30-40 mils per year for both wrought and welded specimens. However, later tests run for longer periods, indicated sharply increasing corrosion rates due to intergranular attack. Therefore, only these longer tests are being reported. These results are shown in Tables $\mathrm{X}$. A sharp rise in the corrosion rate can be sear after periods ranging between 240 and 430 hours for welded specimens, and somewhat longer for the wrought specimens. Visual examination of these specimens showed severe inter- 
TABLE VII

$\frac{\text { CORROSION OF WELDED HEAVY NI-O-NEL IN } 4 \mathrm{M} \mathrm{H}_{2} \frac{\mathrm{SO}}{4}}{\text { COrrosion Rate, mils per year }}$

Exposure

Time

solution

Hours

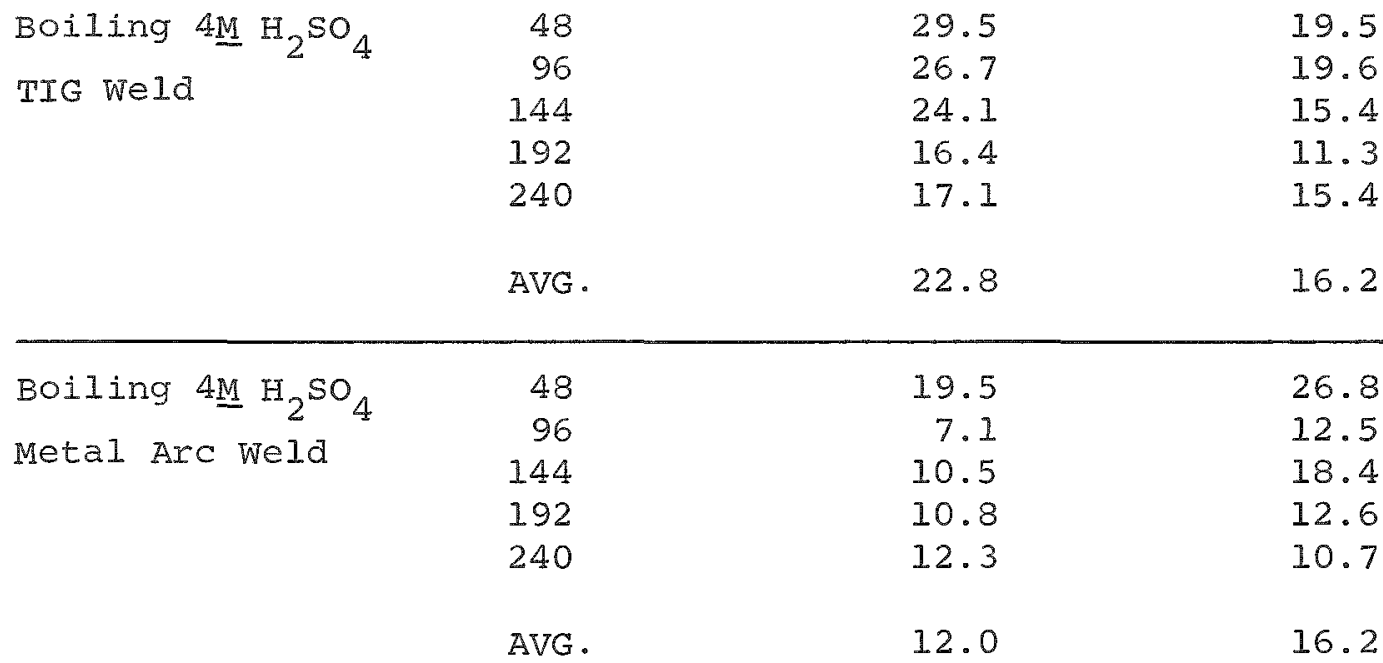

TABLE VIII

$\frac{\text { CORROSION OF CROSS WELDED HEAVY NI-O-NEL IN } 4 \mathrm{M} \mathrm{H}}{\text { Corrosion Rate, mils per year }} 4$

Exposure

Time

solution

Hours

Boiling $4 \mathrm{M} \mathrm{H}_{2} \mathrm{SO}_{4}$

48

TIG Cross welds

96

17.4

34.9

144

13.3

16.4

192

12.6

11.0

240

29.0

12.3

7.4

9.3

AVG .

16.0

16.8

Boiling $4 \mathrm{M} \mathrm{H}_{2} \mathrm{SO}_{4}$

Metal Arc Cross

welds

$\begin{array}{rrr}48 & 27.6 & 28.8 \\ 96 & 25.2 & 33.4 \\ 144 & 9.6 & 8.1 \\ 192 & 11.9 & 11.8 \\ 240 & 23.9 & 14.4 \\ & & \\ \text { AVG } & 19.6 & 19.3\end{array}$


TABLE IX

CORROSION OF WELDED NI-O-NEL IN $4 \mathrm{M} \mathrm{H} \mathrm{H}_{2} \mathrm{SO}_{4}$ PLUS DISSOLVED STAINLESS STEEL

Corrosion Rate, mils per year

Exposure

Time

solution

Hours

\begin{tabular}{|c|c|c|c|}
\hline Boiling $4 \mathrm{M} \mathrm{H}_{2} \mathrm{SO}_{4}+$ & 48 & 4.6 & 6.4 \\
\hline $25 \mathrm{~g} / 1$ dissolved & 96 & 26.3 & 31.2 \\
\hline $209 / 1$ dissolved & 144 & 4.9 & 5.7 \\
\hline 348 s.S. & 192 & 34.0 & 39.0 \\
\hline Metal Arc Weld & 240 & 33.6 & 39.2 \\
\hline & AVG. & 20.7 & 24.3 \\
\hline Boiling $4 \mathrm{M} \mathrm{H}_{2} \mathrm{SO}_{4}+$ & 48 & 9.8 & 10.2 \\
\hline $25 \mathrm{~g} / 1$ dissolved & 96 & 11.7 & 10.6 \\
\hline 259 & 144 & 16.2 & 14.8 \\
\hline 348 S.S. & 192 & 2.8 & 20.4 \\
\hline TIG Weld & 240 & 1.5 & 2.2 \\
\hline & AVG. & 8.4 & 11.6 \\
\hline Boiling $4 \mathrm{M} \mathrm{H}_{2} \mathrm{SO}_{4}+$ & 48 & 2.2 & 2.4 \\
\hline $25 \mathrm{~g} / 1$ dissolved & 96 & 6.9 & 1.8 \\
\hline & 144 & 11.6 & 1.5 \\
\hline 348 s.S. & 192 & 1.6 & 1.3 \\
\hline Heavy TIG Weld & 240 & 1.2 & 1.3 \\
\hline & AVG. & 4.7 & 1.7 \\
\hline Boiling $4 \mathrm{M} \mathrm{H}_{2} \mathrm{SO}_{4}+$ & 48 & 7.5 & 6.7 \\
\hline $25 \mathrm{~g} / \mathrm{l}$ dissolved & 96 & 7.2 & 6.9 \\
\hline & 144 & 10.9 & 6.9 \\
\hline 348 s.s. & 192 & 10.2 & 10.1 \\
\hline Heavy Metal Arc Weld & 240 & 8.8 & 8.8 \\
\hline & AVG. & 8.9 & 7.9 \\
\hline
\end{tabular}


TABLE $X$

$\frac{\text { CORROSION OF NI-O-NEL IN } 6 \mathrm{M} \mathrm{H}_{2}}{\text { Corrosion Rate, mils per year }}$

Exposure

Time

solution

Hours

Liquid

22.1

22.6

3.2

5.0

7.2

11.3

28.0

62.6

45.0

90.6

432

480

Boiling
Wrought
$6 \mathrm{M} \mathrm{H}_{2} \mathrm{SO}_{4}$

48

96
144

192

240

288

336

384

432

480

528

576

624

672

720

768

816
Vapor

14.7
11.6
1.7
1.6
5.4
6.2
13.3
26.6
16.8
50.1

14.7

1.6

1.6

5.4

6.2

13.3

16.8

50.1
Liquid Vapor

8.3

10.7

14.4

34.6

64.0

50.5

110.2

5.9

2.0

4.3

2.5

4.2

4.5

3.5
25.6 Boiling $6 \mathrm{M}_{2} \mathrm{H}_{2} \mathrm{SO}_{4} \quad 26.9$

23.7 Metal Arc weld 33.2

24.0 Metal Arc Weld 24.2

$32.6 \quad 38.3$

29.8

11.1

11.5

21.6

25.3

28.4

24.7

32.4

13.9

38.5

18.8

57.5

134
16.3

16.2

25.0

12.0

28.3

12.7

32.6

59.8 
granular attack of the base metal, with no visible attack of the weld. In two 240 hour tests, 25 grams per liter of dissolved stainless steel had no effect on the corrosion rate in $6 \underline{M}$ sulfuric acid.

On the basis of these results it is apparent that Ni-o-nel is unsuitable for long term service in $6 \mathrm{M}$ sulfuric acid.

C. Corrosion of Heat Transfer surfaces

Since the surfaces of heating coils in a dissolver vessel will be at some temperature above the boiling point of the solution it is necessary to determine the effect of metal surface temperature on the corrosion rate. For this purpose, an apparatus similar to that developed by Groves(5) was used, and is shown in Fig. 5. The sample was a one quarter inch disk heated from below by the soldering iron. The head of the soldering iron was removed and replaced with an aluminum adapter to hold the sample. Teflon gaskets were used to assemble the apparatus. Thermocouples were inserted in the mid-point of the specimen and in the solution. Auxiliary heating was provided to control the solution temperature independently of the metal surface temperature. Rough calculations indicated that the temperature gradient from the mid-point to the surface of the specimen was not more than 5 degrees $F$, and probably about 2 degrees $F$. Because of the problem of crevice corrosion which resulted from improper seating of the gasket, the apparatus was not disassembled during the course of a run. In earlier runs when it was attempted to weigh the specimen after each forty eight period, crevice corrosion resulted unless the gasket was positioned in precisely the same location each time. 
The results of heat transfer tests with sulfuric acid are shown in Table XI. The corrosion rate in $4 \mathrm{M}$ sulfuric acid is independent of the metal surface temperature from the solution boiling point up to 300 degrees $F$, and is slightly lowered by the presence of dissolved stainless steel.

III. Ni-o-ne1 - Nitric Acid

\section{A. Isothermal Tests}

Initial tests in this system were run with liquid phase specimens only for 240 hour periods and showed corrosion rates of less than one mil per year in $4 \underline{M}$ nitric acid and two to four mils per year in 10M nitric acid for both wrought and welded specimens. However, later results showed that vapor phase corrosion was a serjous problem in this system, and a series of long term tests with both liquid and vapor phase specimens were run.

The results of tests in 8 and 10M nitric acid are shown in Table XII. In both these solutions there was a rapidly increasing corrosion rate of the vapor phase specimen due to severe intergranular attack. In the case of welded specimens there was preferential attack of the base metal. In all cases, the buildup of corrosion products in solution resulting from vapor phase attack caused an accelerated corrosion rate in the liquid phase.

A similar run, using a wrought specimen, was made using C.P. nitric acid in order to determine whether the vapor phase attack might be due to the presence of a volatile impurity in technical grade acid. The results proved to be independent of the grade of acid used. 
CORROSION OF NI-O-NEL HEAT TRANSFER SURFACES IN $4 \mathrm{M} \mathrm{H}_{2} \mathrm{SO}_{4}$

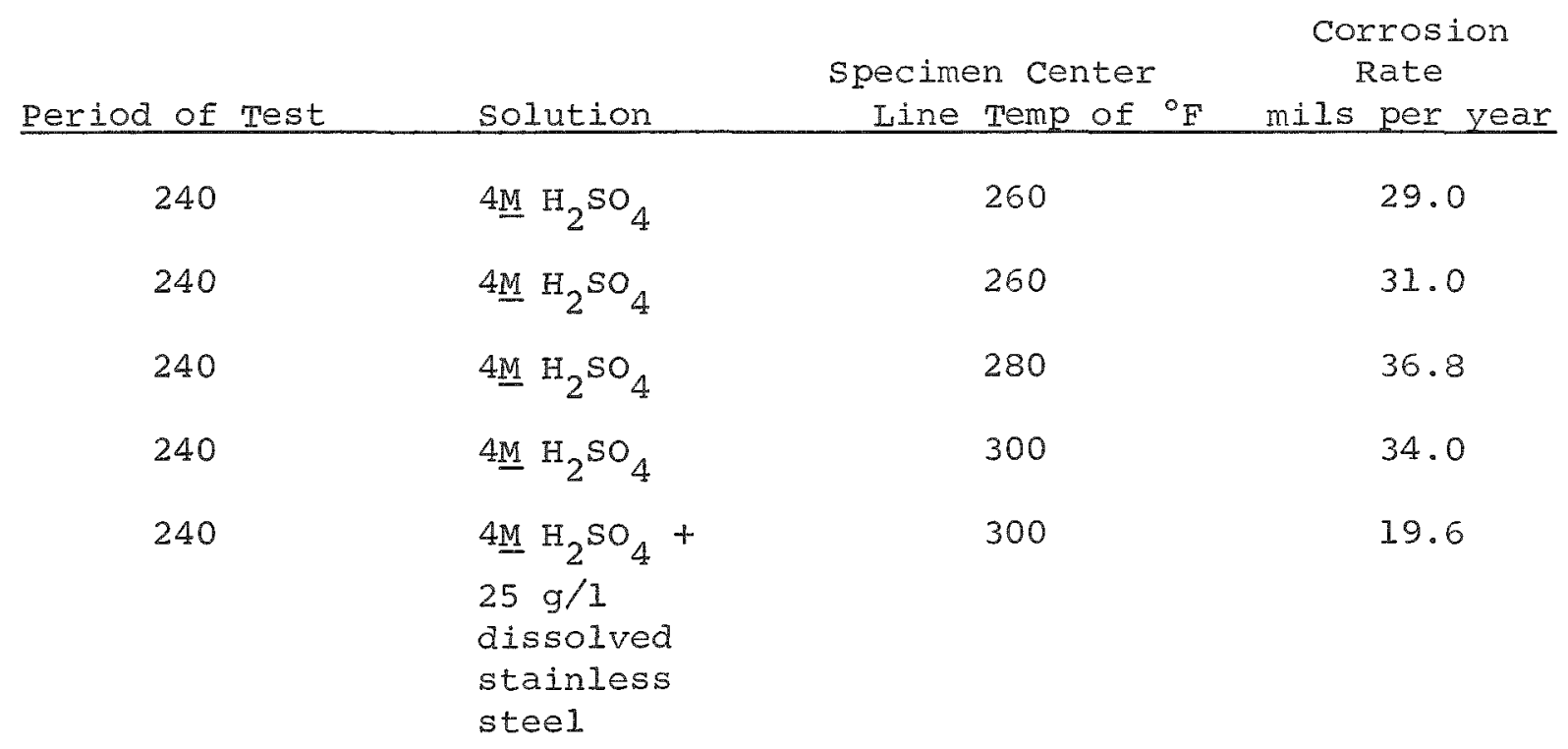


TABLE XII

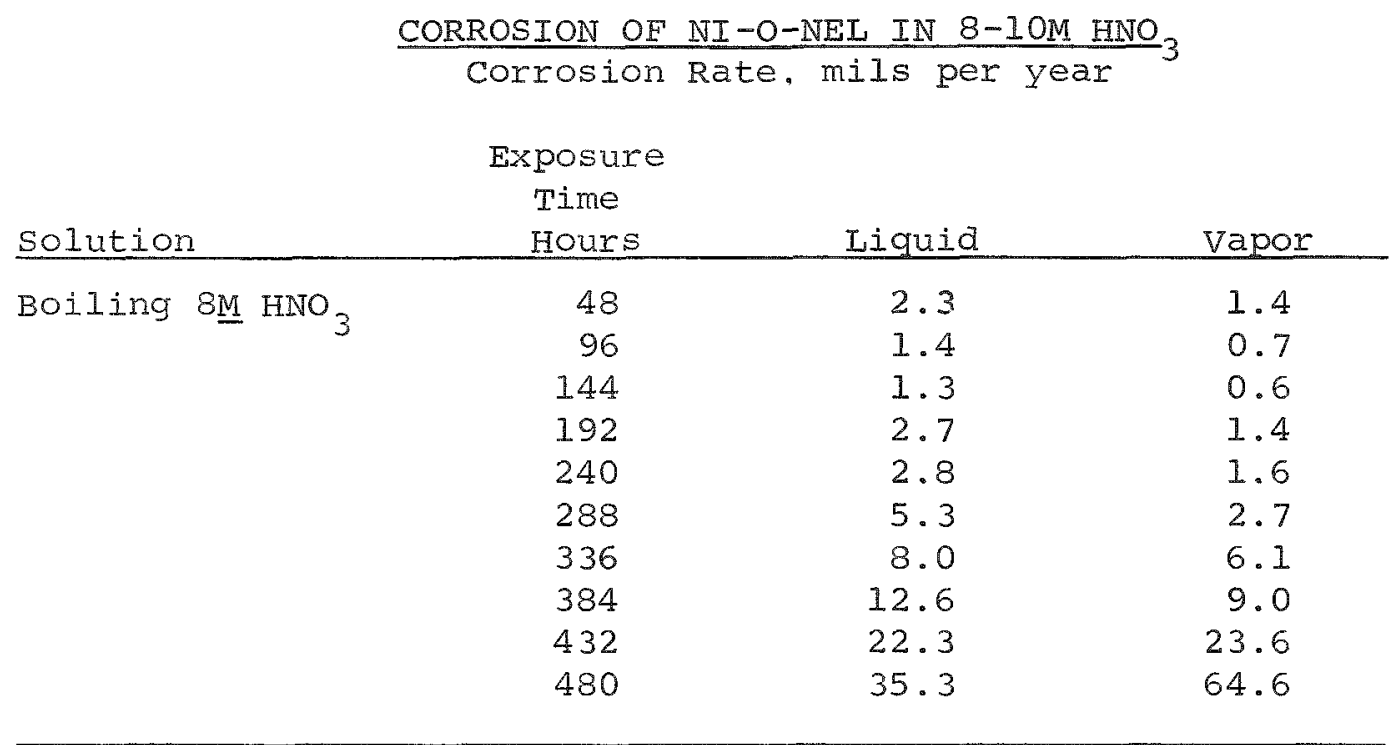

\begin{tabular}{|c|c|c|c|}
\hline Solution & & Liquid Phase & Vapor Phase \\
\hline BOiling IOM $\mathrm{HNO}_{3}$ & $\begin{array}{r}48 \\
96 \\
144 \\
192 \\
240\end{array}$ & $\begin{array}{r}3.4 \\
4.6 \\
16.0 \\
87.0 \\
317\end{array}$ & $\begin{array}{r}1.9 \\
2.3 \\
93.0 \\
294 \\
655\end{array}$ \\
\hline $\begin{array}{l}\text { Boiling lom } \mathrm{HNO}_{3} \\
\text { Metal Arc weld }\end{array}$ & $\begin{array}{r}48 \\
96 \\
144 \\
192 \\
240\end{array}$ & $\begin{array}{r}6.9 \\
8.8 \\
9.7 \\
10.0 \\
12.9\end{array}$ & $\begin{array}{r}4.3 \\
5.3 \\
8.1 \\
20.6 \\
133\end{array}$ \\
\hline $\begin{array}{l}\text { BOiling lOM } \mathrm{HNO}_{3} \\
\text { TIG Weld }\end{array}$ & $\begin{array}{r}48 \\
96 \\
144 \\
192 \\
240\end{array}$ & $\begin{array}{l}5.9 \\
14.5 \\
46.1 \\
111 \\
348\end{array}$ & $\begin{array}{l}10.3 \\
20.8 \\
211 \\
202 \\
688\end{array}$ \\
\hline
\end{tabular}


In order to check the apparatus and technique, a 240 hour test was run with $304 \mathrm{~L}$ stainless steel in 10M nitric acid. This test showed average corrosion rates of 3.2 mils per year in the liquid. phase and 4.3 mils per year in the vapor phase, and the rates were constant throughout the tests. Thus the apparatus and techniques appeared to be satisfactory.

Results in 5M nitric acid are shown in Table XIII. Vapor phase attack is much less severe in this case but there was definite evidence of intergranular attack, with corrosion rates reaching 40 to 50 mils per year after about 1800 hours. A similar test was run with wrought specimens, and showed a vapor phase corrosion rate of $4 \mathrm{mils}$ per year after 1344 hours, when the test was terminated. One test in 6M nitric acid was run for 1008 hours, with the vapor phase specimen showing a corrosion rate of 4 mils per year at that time. vapor phase specimens were also inserted in four heat transfer tests in 5 M nitric acid, with the solution maintained at 90 degrees $C$. Under these conditions, there was no measurable vapor phase corrosion for periods up to 624 hours. On the basis of these results, it would appear to be desirable to conduct core dissolutions in a Ni-o-nel vessel below the boiling point.

Several tests were also run to determine the effects of a heel from the decladding solution on nitric acid corrosion rates in the liquid phase. In these runs the solutions were made $0.025 \mathrm{M}$ in sulfuric acid and $0.0077 \mathrm{M}$ in stainless steel. Runs were made in both 4 and 1OM nitric acid and were run for 240 hours. Both wrought and 
TABLE XIII

CORROSION OF NI-O-NEL IN 5M HNO 3

Corrosion Rate, mils per year

\begin{tabular}{|c|c|c|c|c|c|c|c|}
\hline Solution & $\begin{array}{l}\text { Txposure } \\
\text { Time } \\
\text { Hours }\end{array}$ & Liquid & Vapor & Solution & $\begin{array}{l}\text { posure } \\
\text { Time } \\
\text { Hours } \\
\end{array}$ & Liquid & Vapor \\
\hline Boiling $5 \mathrm{M} \mathrm{HNO}_{3}$ & 48 & 0.4 & 0.1 & BOiling $5 \mathrm{M} \mathrm{HNO}_{2}$ & 48 & 0.7 & \\
\hline 3 & 96 & 0.9 & 0.6 & Metal xros & 96 & 1.6 & 0.9 \\
\hline TIG Weld & 144 & 0.7 & 0.4 & Metal Arc weld & 144 & 1.5 & 0.4 \\
\hline & 192 & 0.9 & 1.3 & & 192 & 1.4 & 0.9 \\
\hline & 240 & 0.8 & 0.7 & & 240 & 1.3 & 0.7 \\
\hline & 288 & 1.0 & 0.6 & & 288 & 1.8 & 0.5 \\
\hline & 336 & 1.3 & 1.0 & & 336 & 1.6 & 1.2 \\
\hline 1 & 384 & 1.4 & 1.0 & & 384 & 3.7 & 2.0 \\
\hline U & 432 & 2.6 & 2.6 & & 432 & 5.1 & 3.2 \\
\hline 1 & 480 & 1.8 & 2.0 & & 480 & 3.6 & 2.9 \\
\hline & 528 & 1.9 & 1.3 & & 528 & 3.7 & 2.1 \\
\hline & 576 & 1.6 & 1.4 & & 576 & 2.9 & 1.6 \\
\hline & 624 & 2.2 & 1.4 & & 624 & 3.0 & 2.2 \\
\hline & 672 & 1.9 & 0.8 & & 672 & 3.3 & 2.5 \\
\hline & 720 & 1.9 & 1.5 & & 720 & 3.2 & 3.4 \\
\hline & 768 & 1.9 & 2.3 & & 768 & 3.6 & 2.5 \\
\hline & 816 & 2.5 & 1.5 & & 816 & 2.7 & 2.5 \\
\hline & 864 & 1.8 & 1.9 & & 864 & 3.6 & 2.9 \\
\hline & 912 & 2.0 & 2.4 & & 912 & 2.7 & 2.7 \\
\hline & 960 & 1.9 & 2.4 & & 960 & 3.1 & 2.8 \\
\hline & 1008 & 2.5 & 2.5 & & 1008 & 3.2 & 5.3 \\
\hline & 1056 & 2.5 & 3.4 & & 1056 & 3.4 & 5.9 \\
\hline & 1104 & 2.9 & 3.0 & & 1104 & 3.4 & 4.0 \\
\hline & 1152 & 2.2 & 3.6 & & 1152 & 3.2 & 8.6 \\
\hline & 1200 & 4.2 & 4.6 & & 1200 & 3.4 & 5.6 \\
\hline & 1248 & 2.3 & 3.7 & & 1248 & 4.2 & 9.1 \\
\hline
\end{tabular}


TABLE XIII (cont.)

CORROSION OF NI-O-NEL IN $5 \mathrm{M}$ HNO $_{3}$ Corrosion Rate, mils per year

\begin{tabular}{|c|c|c|c|c|c|c|c|}
\hline Solution & $\begin{array}{l}\text { xposure } \\
\text { Time } \\
\text { Hours } \\
\end{array}$ & Liquid & \multicolumn{3}{|c|}{$\begin{array}{c}\text { Exposure } \\
\text { Time }\end{array}$} & & Vapor \\
\hline $\mathrm{BOIling} \mathrm{M}_{\mathrm{HNO}}$ & 1296 & 2.7 & 2.7 & & 1296 & 3.7 & 8.0 \\
\hline TTG Weld & 1344 & 2.1 & 1.5 & & 1344 & 3.6 & 6.6 \\
\hline TIG Weld & 1392 & 2.1 & 3.4 & Metal Arc weld & 1392 & 3.9 & 12.2 \\
\hline$\omega$ & 1440 & 2.5 & 4.9 & & 1440 & 4.2 & 14.3 \\
\hline 1 & 1488 & 3.3 & 6.2 & & 1488 & 3.9 & 13.6 \\
\hline & 1536 & 4.4 & 8.0 & & 1536 & 4.6 & 22.5 \\
\hline & 1584 & 4.9 & 12.3 & & 1584 & 4.4 & 19.7 \\
\hline & 1632 & 4.4 & 12.7 & & 1632 & 5.0 & $25 \cdot 6$ \\
\hline & 1680 & 3.5 & 13.3 & & 1680 & 4.8 & 23.8 \\
\hline & 1728 & 4.7 & 14.4 & & & & \\
\hline & 1776 & 5.2 & 51.1 & & & & \\
\hline & 1824 & 5.3 & 39.6 & & & & \\
\hline & 1872 & 4.8 & 48.6 & & & & \\
\hline & 1920 & 4.6 & 47.2 & & & & \\
\hline & 1968 & 4.4 & 43.2 & & & & \\
\hline
\end{tabular}


all types of welded specimens were tested. The presence of a heel had no effect on corrosion rates in any case. Several tests were run to determine the effect of boric acid in solution on nitric acid corrosion rates. Boric acid may be useful as a soluble poison in dissolving enriched fuels, and in these runs 3 grams per liter of boron was added to $10 \underline{M}$ nitric acid. Tests were run with liquid phase specimens only for 240 hours. and the presence of boron had no effect on the corrosion rate.

Photomicrographs of welded Ni-o-nel specimens exposed to $4 \mathrm{MNO}_{3}$ plus a heel, and to the vapor phase over $10 \mathrm{M} \mathrm{HNO}_{3}$, both for 240 hours, are shown in Figs. $6 \& 7$.

\section{B. Heat Transfer Tests}

The results of corrosion tests of Ni-o-nel heat transfer surfaces in nitric acid are shown in Table XIV. It is apparent that 10M nitric acid could not be used for core dissolution in a Ni-o-nel vessel. Even the isothermal tests, during which the specimen centerline temperature was controlled to \pm 5 degrees $F$ of the boiling point, showed severe corrosion. The attack in all cases was intergranular.

With $5 \mathrm{M} \mathrm{HNO}_{3}$, intergranular attack was noted in all tests except the isothermal one, and was severe with specimen centerline temperatures over $240^{\circ} \mathrm{F}$. There is a very sharp increase in the corrosion rate at temperatures between 240 and $250^{\circ} \mathrm{F}$, and even at $240^{\circ} \mathrm{F}$, the corrosion rate reached 21.9 mils per year after 768 hours of exposure. The corrosion rate appeared to be independent of the solution temperature, depending only on the metal surface temperature. Thus there may 
CORROSION OF NI-O-NEL HEAT TRANSFER SURFACES BY 5-1OM HNO 3

\begin{tabular}{|c|c|c|c|c|}
\hline $\begin{array}{r}\text { Period of Test } \\
\text { Hours }\end{array}$ & Solution & & $\begin{array}{l}\text { pecimen center } \\
\text { Line Temp of }\end{array}$ & $\begin{array}{c}\text { Corrosion } \\
\text { Rate } \\
\text { mils per year } \\
\end{array}$ \\
\hline 240 & $10 \mathrm{M} \mathrm{HNO}_{3}$ & & 242 & 185 \\
\hline 240 & $10 \mathrm{M} \mathrm{HNO}_{3}^{3}$ & & 260 & 1430 \\
\hline 240 & LOM HNO & & 280 & 1030 \\
\hline 240 & $10 \bar{M} \mathrm{HNO}_{3}^{3}$ & & 300 & 185 \\
\hline 624 & $5 \overline{\mathrm{M}} \mathrm{HNO}_{3}^{3}$ & & 226 & 3.2 \\
\hline 624 & $5 \overline{\mathrm{M}} \mathrm{HNO}_{2}^{3}$ & $\left(90^{\circ} \mathrm{C}\right)$ & 226 & 7.7 \\
\hline 768 & $5 \overline{\mathrm{M}} \mathrm{HNO}_{3}^{3}$ & & 240 & 21.9 \\
\hline 480 & $5 \overline{\mathrm{M}} \mathrm{HNO}_{3}^{3}$ & & 242 & 8.4 \\
\hline 480 & $5 \mathrm{M} \mathrm{HNO}_{3}^{3}$ & & 247 & 145 \\
\hline 432 & $5 \overline{\mathrm{M}} \mathrm{HNO}_{3}^{3}$ & & 250 & 230 \\
\hline 240 & $5 \overline{\mathrm{M}} \mathrm{HNO}_{3}^{3}$ & & 260 & 23.7 \\
\hline 336 & $5 \bar{M} \mathrm{HNO}_{3}^{3}$ & & 260 & 378 \\
\hline 672 & $5 \mathrm{M} \mathrm{HNO}_{3}^{3}$ & $\left(90^{\circ} \mathrm{C}\right)$ & 260 & 370 \\
\hline 240 & $5 \overline{\mathrm{M}} \mathrm{HNO}_{3}^{3}$ & & 300 & 56.7 \\
\hline
\end{tabular}


be serious corrosion of Ni-o-nel heat transfer surfaces during core dissolutions even using $5 \mathrm{M}^{\mathrm{HNO}} \mathrm{HN}_{3}$ below the boiling point. In order to minimize this problem, heat transfer surfaces should be maintained at a temperature below $240^{\circ} \mathrm{F}$.

IV. Carpenter $20-$ sulfex

Carpenter 20 has been considered as an alternate material of construction for the sulfex process, and therefore it was also tested in sulfex solutions. These tests were less extensive than those with Ni-o-nel, because Carpenter 20 seemed to show no advantage over Ni-o-nel, and may have certain disadvantages.

\section{A. Sulfuric Acid Tests}

The results of tests in $4 \underline{M}$ sulfuric acid are shown in Table $X V$. In general, these rates are very similar to those observed in Ni-o-nel sulfuric acid system, except that in the case of carpenter 20, welded specimens corroded at almost double the rate of wrought specimens. Dissolved stainless steel lowered the corrosion rate by about the same order of magnitude as with Ni-o-nel. No tests were done in this system at higher sulfuric acid concentrations, or with vapor phase or heat transfer surfaces.

\section{B. Nitric Acid Tests}

The results of liquid phase tests in nitric acid are shown in Table XVI. The results with wrought specimens are about the same as those observed with Ni-o-nel, but the corrosion rates increased by a factor of five to ten with inert gas welded specimens, and were completely unsatisfactory with fusion welded specimens. One additional 
TABLE XV

CORROSION OF CARPENTER 2OCl IN 4M H $\mathrm{SO}_{4}$ Corrosion Rate. mils per year

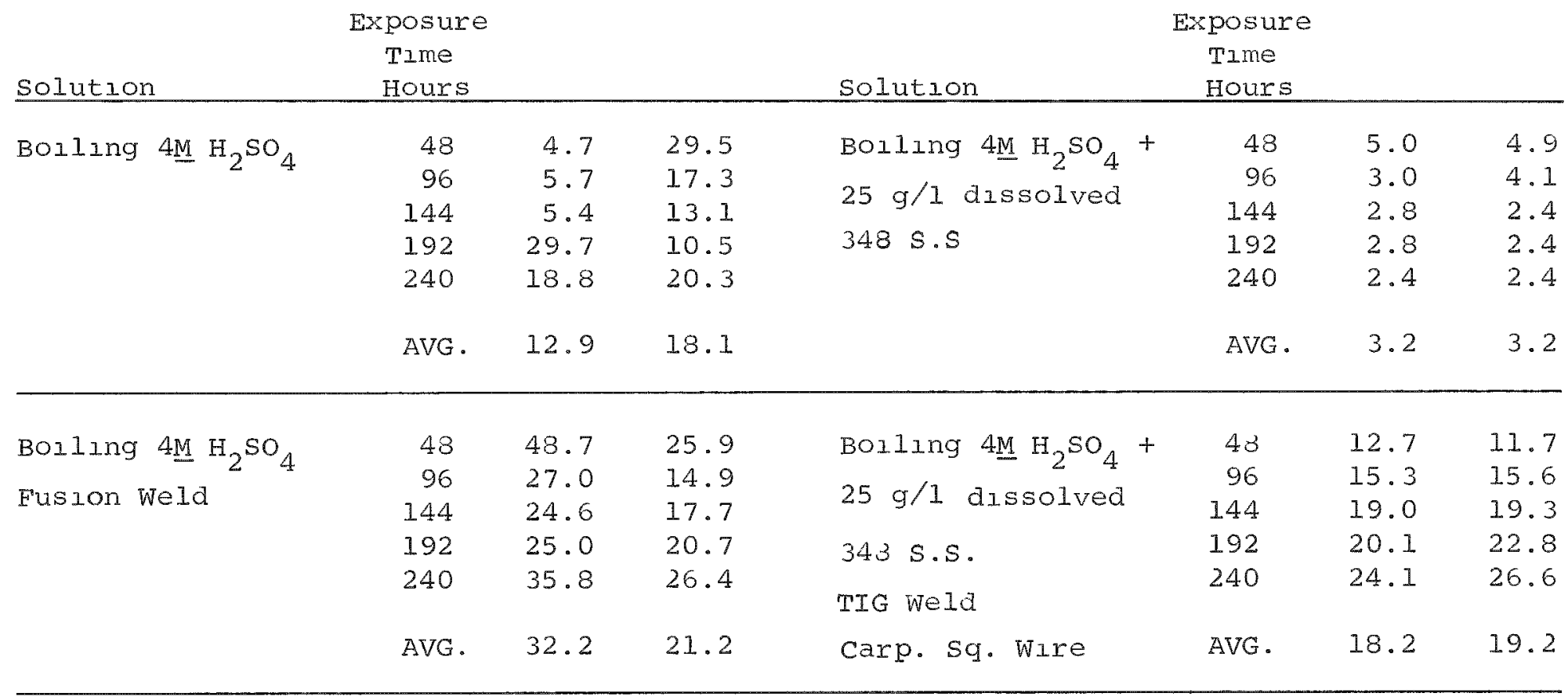

$\begin{array}{lrrr}\text { Boling } 4 \mathrm{M} \mathrm{H} \mathrm{SO}_{4} & 48 & 25.8 & 31.0 \\ \text { TIG WeId } & 96 & 23.5 & 90.7 \\ & 144 & 16.0 & 11.2 \\ & 192 & 3.5 & 2.9 \\ & 240 & 46.5 & 4.0 \\ & & & \\ & \text { AVG. } & 23.0 & 28.0\end{array}$


TABLE XVI

CORROSION OF CARPENTER 20C. IN 4-1OM HNO 3 Corrosion Rate, mils per year

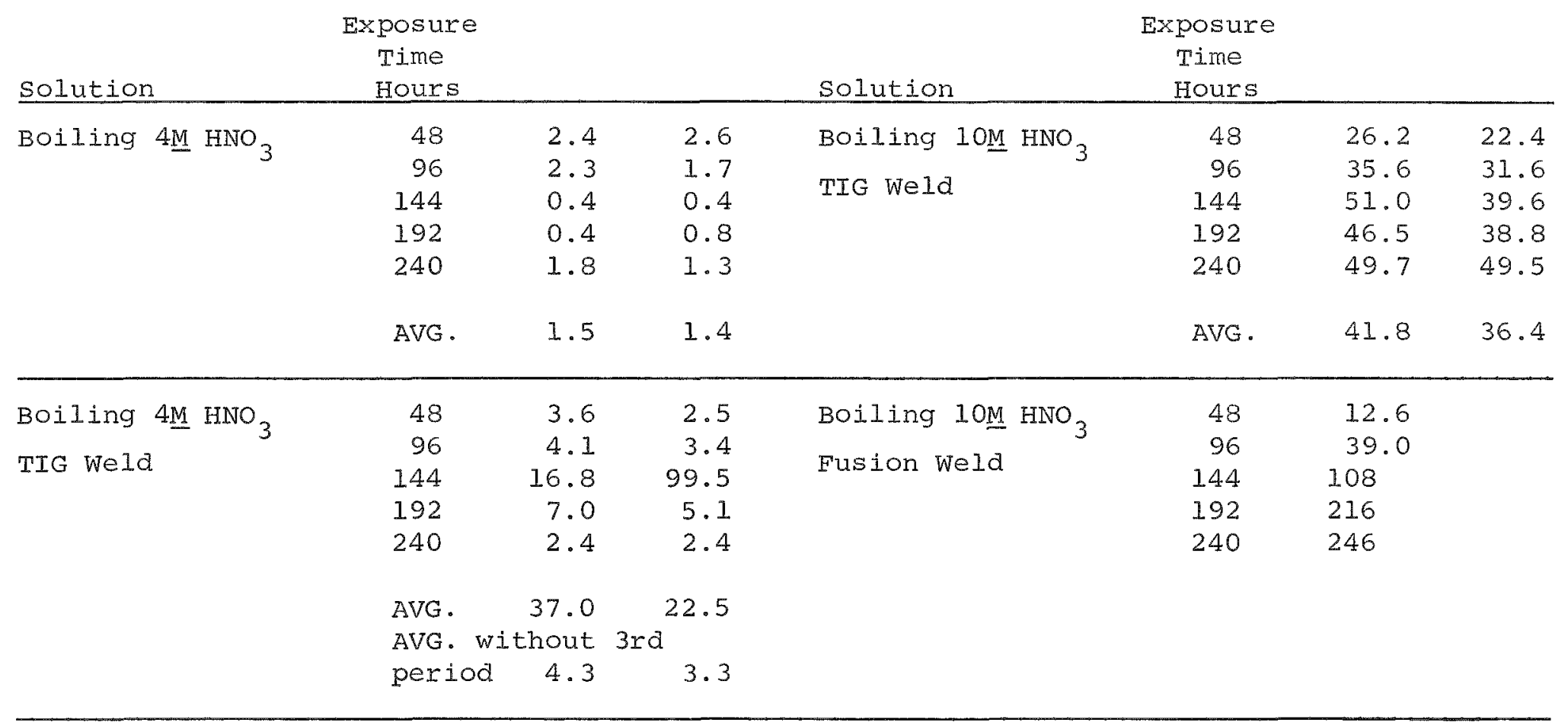

\begin{tabular}{|c|c|c|c|c|c|c|c|}
\hline & & & & & & Liquid & Vapor \\
\hline \multirow{7}{*}{ BOiling $10 \mathrm{M} \mathrm{HNO}_{3}$} & 48 & 10.0 & 10.0 & \multirow{7}{*}{ BOiling $10 \mathrm{M} \mathrm{HNO}_{3}$} & 48 & 3.8 & 2.8 \\
\hline & 96 & 5.7 & 5.2 & & 96 & 4.5 & 3.2 \\
\hline & 144 & 4.4 & 3.2 & & 144 & 4.3 & 4.4 \\
\hline & 192 & 4.2 & 2.8 & & 192 & 4.0 & 4.8 \\
\hline & \multirow[t]{2}{*}{240} & 5.0 & 0.5 & & 240 & 4.3 & 7.2 \\
\hline & & & & & 288 & 3.8 & 8.9 \\
\hline & AVG. & 5.8 & 4.3 & & 336 & 3.8 & 18.7 \\
\hline
\end{tabular}


test was done in 10M nitric acid, which included a vapor phase specimen. This result is shown in Table XVII. The vapor phase specimen showed a continually increasing corrosion rate, and by the termination of the test. there was visual evidence of accelerating intergranular attack.

Because of the generally poor performance of carpenter 20 welds, particularly in nitric acid, and since the nitric acid vapor phase corrosion problem appeared to be no less serious with carpenter 20 than with Ni-o-nel, no further work was done with Carpenter 20 in sulfex solutions.

\section{Zirflex Corrosion studies}

\section{A. $\quad 309 \mathrm{SCb}$}

Tests with $309 \mathrm{scb}$ in uninhibited zirflex solutions showed obviously unsatisfactory corrosion rates of about 150 mils per year in forty eight hour tests. The presence of dissolved zircalloy at concentrations of 0.3 and $0.5 \mathrm{M}$ had no effect on the corrosion rate, but a concentration of $0.75 \mathrm{M}$ lowered the corrosion rate to about 2 mils per year. It was not possible to determine the effect of dissolving Zircalloy, since short term tests even in the absence of dissolving Zircalloy showed low but erratic corrosion rates.

The effect of hydrogen peroxide on corrosion rates was studied very briefly and preliminary results indicate that it may be an effective inhibitor, but that it may be necessary to make continuous or periodic additions in order to maintain a sufficient concentration in solution. For instance, with $1 \mathrm{M} \mathrm{H}_{2} \mathrm{O}_{2}$, the corrosion rate in a 24 hour test was 43.8 mils per year, but in a 48 hour test it was 122 
mils per year. Further studies of the stability of peroxide in these solutions are needed.

The effect of cupric nitrate on corrosion rates was studied somewhat more extensively, and these results are shown in Table XVII. The addition of $0.01 \mathrm{M}$ cupric ion lowers the corrosion rate by a factor of four to five, and the addition of $0.1 \mathrm{M}$ cupric ion is somewhat less effective. Copper is slowly lost from these solutions by plating out on stainless steel surfaces, particularly welds. but the loss is slow enough so that additions during a dissolution should not be necessary. There was never evidence of loss of copper before 48 hours. Thus in the presence of $0.01 \mathrm{M}$ cupric ion a corrosion rate of 30-40 mils per year would be expected. in the starting solution and this may be lower in the presence of dissolving zircalloy, and would certainly be lower in the final solution. several tests at 90 degrees C showed corrosion rates in this solution of only two to four mils per year, but zircalloy dissolution rates at this temperature were unsatisfactory. Vapor phase corrosion rates in this system are negligible. Further work is necessary to determine the effect of both peroxide and cupric ion on core losses.

$$
\text { B. } 304 \mathrm{~L}
$$

The corrosion rate of $304 \mathrm{~L}$ in uninhibited zirflex solutions is also unsatisfactory, averaging about $300 \mathrm{mils}$ per year. The effect of cupric ion on corrosion of $304 \mathrm{I}$ stainless steel by zirflex solutions is shown in Table XVIII. The loss of copper from solution is much more rapid and less predictable than with $309 \mathrm{scb}$. Therefore the corrosion 
TABLE XVII

CORROSION OF $309 \mathrm{SCD}$ BY ZIRFLEX SOLUTIONS

Corrosion Rate, mils per year

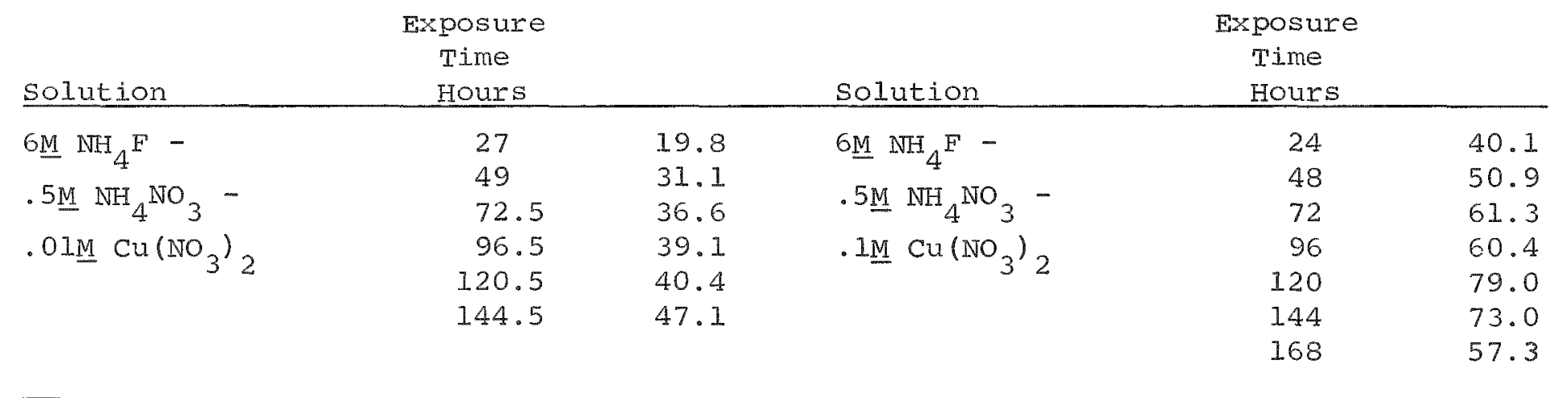

$\begin{array}{lr}6 \mathrm{M}_{4} \mathrm{~F}- & 24 \\ .5 \mathrm{M} \mathrm{NH}_{4} \mathrm{NO}_{3}- & 48 \\ .01 \mathrm{M} \mathrm{Cu}\left(\mathrm{NO}_{3}\right)_{2} & 72 \\ \text { TIG Weld } & 96 \\ \end{array}$

Iiquid Phase

Vapor phase

TIG Weld

$\begin{array}{ll}37.0 & 1.5 \\ 31.8 & 0 \\ 31.1 & 0 \\ 29.9 & 0 \\ 30.6 & 0\end{array}$


TABLE XVIII

CORROSION OF 304L BY ZIRFLEX SOLUTIONS

Corrosion Rate, mils per year

\begin{tabular}{|c|c|c|c|}
\hline Solution & $\begin{array}{l}\text { posur } \\
\text { Time } \\
\text { Hours }\end{array}$ & & Remarks \\
\hline $\begin{array}{l}6 \underline{\mathrm{MH}} \mathrm{NH}_{4} \mathrm{~F}-.5 \mathrm{M} \mathrm{NH}_{4} \mathrm{NO}_{3} \\
-.01 \mathrm{M} \mathrm{Cu}\left(\mathrm{NO}_{3}\right)_{2}\end{array}$ & $\begin{array}{l}24 \\
48\end{array}$ & $\begin{array}{l}112 \\
226\end{array}$ & $\begin{array}{l}\text { Slight cu plate } \\
\text { Heavy cu plate }\end{array}$ \\
\hline $\begin{array}{l}6 \underline{\mathrm{M}} \mathrm{NH}_{4} \mathrm{~F}-.5 \underline{\mathrm{M}} \mathrm{NH}_{4} \mathrm{NO}_{3} \\
-.01 \mathrm{M} \mathrm{Cu}\left(\mathrm{NO}_{3}\right)_{2}\end{array}$ & $\begin{array}{l}24 \\
48 \\
72\end{array}$ & $\begin{array}{l}62.5 \\
118 \\
158\end{array}$ & $\begin{array}{l}\text { No Cu plate } \\
\text { Cu plate } \\
\text { Cu plate }\end{array}$ \\
\hline $\begin{array}{l}6 \underline{\underline{M}} \mathrm{NH}_{4} \mathrm{~F}-.5 \mathrm{M}_{4} \mathrm{NH}_{4} \mathrm{NO}_{3} \\
-.01 \underline{\mathrm{M}} \mathrm{Cu}\left(\mathrm{NO}_{3}\right)_{2}\end{array}$ & $\begin{array}{r}24 \\
48 \\
72 \\
96 \\
120\end{array}$ & $\begin{array}{l}36.0 \\
38.0 \\
58.4 \\
64.1 \\
58.4\end{array}$ & $\begin{array}{l}\text { No cu plate } \\
\text { No cu plate } \\
\text { slight cu plate } \\
\text { Cu plate } \\
\text { cu plate }\end{array}$ \\
\hline $\begin{array}{l}6 \underline{\mathrm{M}} \mathrm{NH}_{4} \mathrm{~F}-.5 \underline{\mathrm{M}} \mathrm{NH}_{4} \mathrm{NO}_{3} \\
-.01 \underline{\mathrm{M}} \mathrm{Cu}\left(\mathrm{NO}_{3}\right)_{2}\end{array}$ & $\begin{array}{l}24 \\
48 \\
72 \\
96\end{array}$ & $\begin{array}{l}165 \\
249 \\
292 \\
234\end{array}$ & $\begin{array}{l}\text { Heavy cu plate } \\
\text { Heavy cu plate } \\
\text { Heavy cu plate } \\
\text { Heavy cu plate }\end{array}$ \\
\hline $\begin{array}{l}6 \mathrm{M} \mathrm{NH}_{4} \mathrm{~F}-.5 \mathrm{M} \mathrm{NH}_{4} \mathrm{NO}_{3} \\
-. \mathrm{MM} \mathrm{Cu}\left(\mathrm{NO}_{3}\right)_{2}\end{array}$ & $\begin{array}{r}24 \\
48 \\
72 \\
96 \\
120\end{array}$ & $\begin{array}{l}62.0 \\
123 \\
192 \\
222 \\
178\end{array}$ & $\begin{array}{l}\text { No cu plate } \\
\text { No cu plate } \\
\text { slight cu plate } \\
\text { slight cu plate } \\
\text { Heavy cu plate }\end{array}$ \\
\hline $\begin{array}{l}6 \underline{\mathrm{M}} \mathrm{NH}_{4} \mathrm{~F}-.5 \mathrm{M} \mathrm{NH}_{4} \mathrm{NO}_{3} \\
-.1 \mathrm{M} \mathrm{Cu}\left(\mathrm{NO}_{3}\right)_{2}\end{array}$ & $\begin{array}{r}24 \\
48 \\
72 \\
96 \\
120\end{array}$ & $\begin{array}{c}47.1 \\
46.9 \\
55.7 \\
\text { Heater Failed } \\
148\end{array}$ & $\begin{array}{l}\text { No cu plate } \\
\text { No cu plate } \\
\text { No Cu plate } \\
\text { No cu plate } \\
\text { No Cu plate }\end{array}$ \\
\hline $\begin{array}{l}6 \underline{\mathrm{M}} \mathrm{NH}_{4} \mathrm{~F}-.5 \underline{\mathrm{M}} \mathrm{NH}_{4} \mathrm{NO}_{3} \\
-.1 \mathrm{M} \mathrm{Cu}\left(\mathrm{NO}_{3}\right)_{2}\end{array}$ & $\begin{array}{l}24 \\
48\end{array}$ & $\begin{array}{l}110 \\
147\end{array}$ & $\begin{array}{l}\text { No cu plate } \\
\text { No cu plate }\end{array}$ \\
\hline $\begin{array}{l}6 \underline{\mathrm{MH}} \mathrm{NH}_{4} \mathrm{~F}-.5 \mathrm{M} \mathrm{NH}_{4} \mathrm{NO}_{3} \\
-.1 \mathrm{M} \mathrm{Cu}\left(\mathrm{NO}_{3}\right)_{2}\end{array}$ & $\begin{array}{r}24 \\
48 \\
72 \\
96 \\
120\end{array}$ & $\begin{array}{l}46.6 \\
43.3 \\
49.9 \\
47.1 \\
45.0\end{array}$ & $\begin{array}{l}\text { No Cu plate } \\
\text { No Cu plate } \\
\text { No cu plate } \\
\text { No Cu plate } \\
\text { No cu plate }\end{array}$ \\
\hline
\end{tabular}


data show wide scatter but are generally much too high. Cupric ion was the only inhibitor studies in this system, and does not appear to be effective.

\section{Ni-o-nel}

Ni-o-nel showed a corrosion rate of about 250 mils per year in uninhibited zirflex solutions. Dissolved zircalloy at concentrations of 0.3 and $0.5 \mathrm{M}$ had no effect on the corrosion rate, but at a concentration of $0.75 \mathrm{M}$ lowered the corrosion rate to about 10 mils per year. In the presence of dissolving zircalloy, the corrosion rate was lowered to about 30 mils per year, but because of the short period of these tests. the data scattered widely.

Data on the effect of cupric ion as an inhibitor are shown on Table XIX. Cupric ion is not as effective in this system as with $309 \mathrm{scb}$. mainly due to a more rapid loss of inhibitor, and even the inhibited rates do not appear to be satisfactory. Vapor phase corrosion rates are very low in this system.

A photomicrograph of a welded Ni-o-nel specimen exposed zirflex solution containing 0.1 M $C u$ for 120 hours is shown in Fig. 8 . 
TABLE; XIX

CORROSION OF NI-O-NEL BY ZIRFLEX SOLUTIONS

corrosion Rate, mils per year

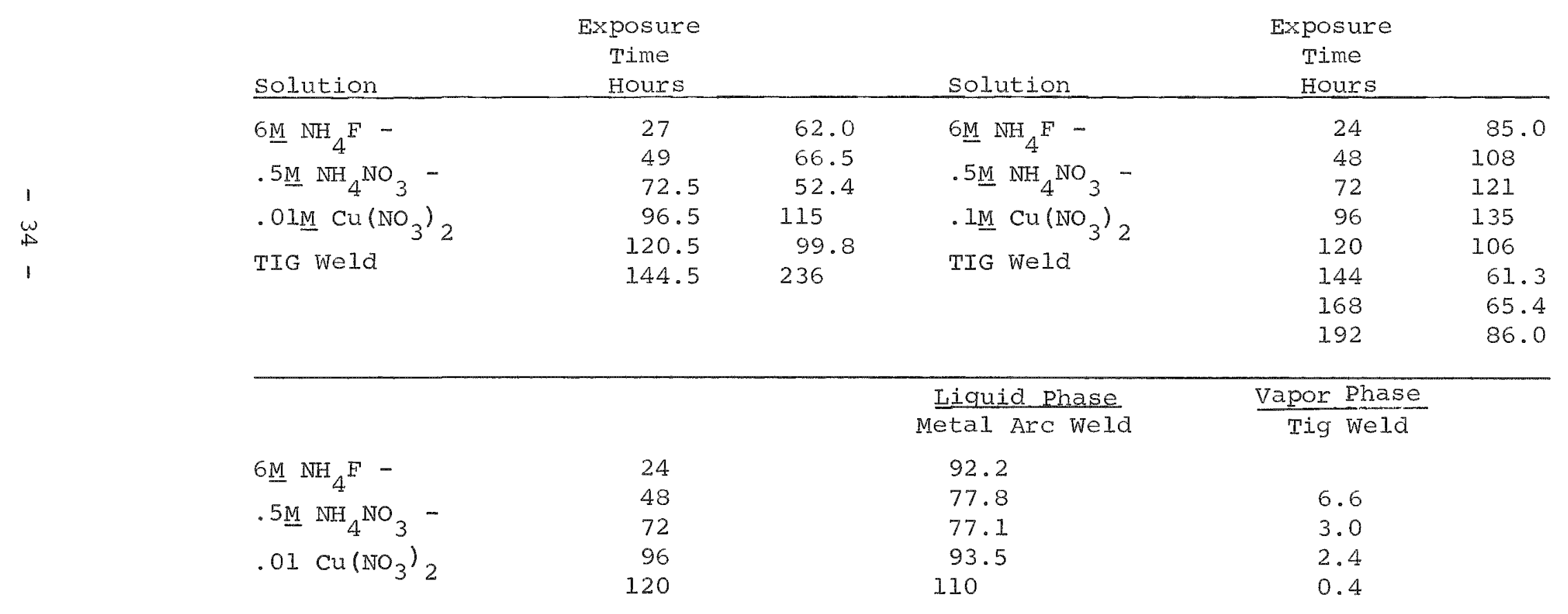




\section{Summary and Conclusions}

1. Ni-o-nel is a satisfactory material of construction for the sulfex process. subject to the following limitations:

a) Sulfuric acid concentration should be limited to $4 \mathrm{M}$. Ni-o-nel is subject to severe intergranular attack in $6 \underline{M}$ sulfuric acid.

b) Nitric acid concentrations should be less than 6M, and maintained below the boiling point, in order to avoid intergranular attack in the vapor phase.

c) Heat transfer surfaces should be maintained at a tomperature less than $240^{\circ} \mathrm{F}$ during core dissolutions.

2. Carpenter 20 is less satisfactory than $\mathrm{Ni}$-o-nel for application to the sulfex process, because of selective attack of welds, particularly in nitric acid solutions.

3. Neither Ni-o-nel or $309 \mathrm{sCb}$ or $304 \mathrm{~L}$ stainless steel are satisfactory for use with uninhibited zirflex solutions.

4. Cupric ion, and possibly peroxide, significantly lower corrosion rates of $309 \mathrm{scb}$ by Zirflex solutions. With $0.01 \mathrm{M}$ cupric ion the corrosion rate is lowered to $30-40 \mathrm{mils}$ per year. Corrosion rates of $\mathrm{Ni}-0-$ nel and $304 \mathrm{~L}$ by Zirflex solutions are considerably higher than this using either of these inhibitors. 


\section{References}

(1) Flanary, J.R.. et al., "Development of the sulfex Process For Decladding stainless steel clad power Reactor Fuel Elements with Sulfuric Acid," ORNL 2461 (March 1959)

(2) Fisher. F.D.. "The Sulfex Process - Terminal Development Report." HW 66439 (August 1960)

(3) Smith, P.W., "The Zirflex Process - Terminal Development Report." HW 65979 (August 1960)

(4) Ferris, L.M., "Decladding of PWR Blanket Fuel Elements With Aqueous Ammonium Fluoride Solutions." ORNL 2553 (September 1958)

(5) Groves. N.D. and Eisenbrown, C.M., "Rating Heat Transfer surfaces For Corrosion," Metal progress (May 1959) 


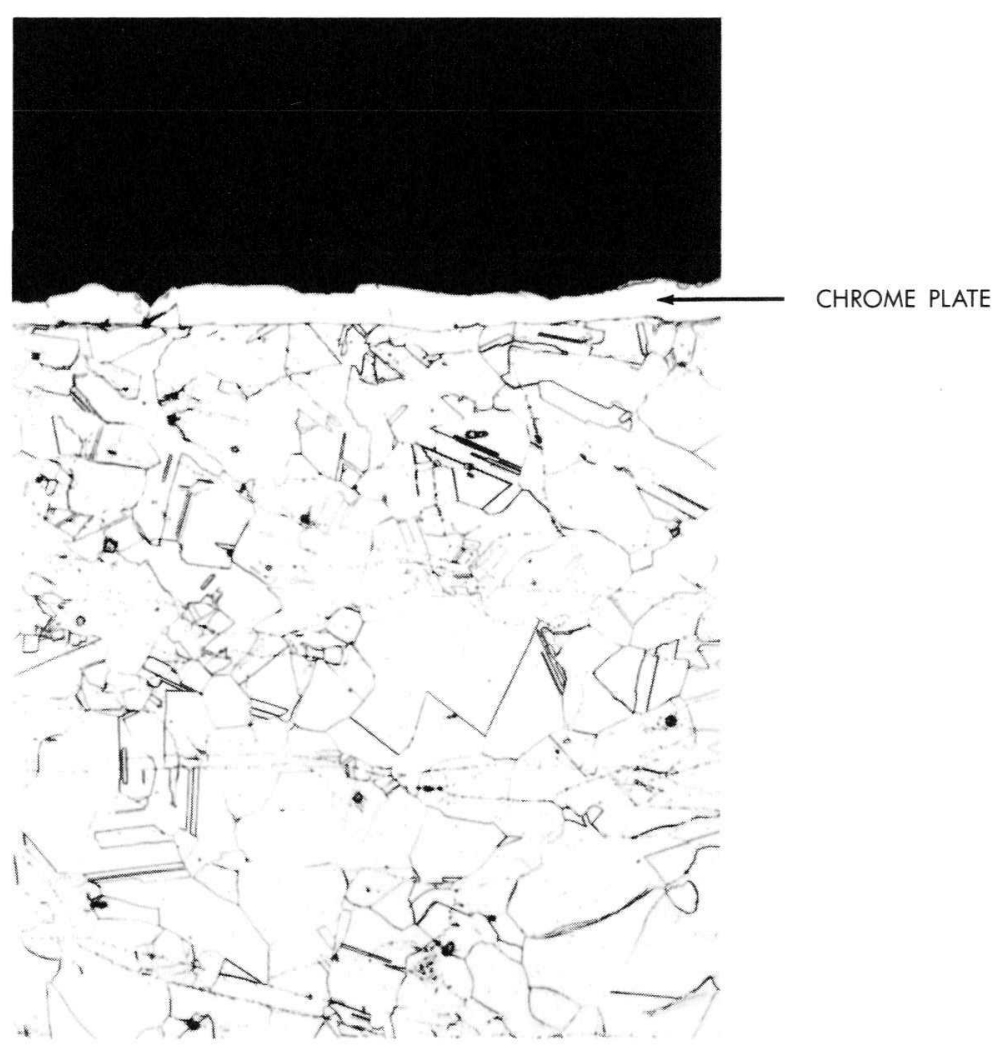

Figure 1. Wrought Ni-o-nel exposed to boiling $4 M \mathrm{H}_{2} \mathrm{SO}_{4}$. Transverse section $-250 \times$. Corrosion rate -22 mils per year - 240 hour exposure. 


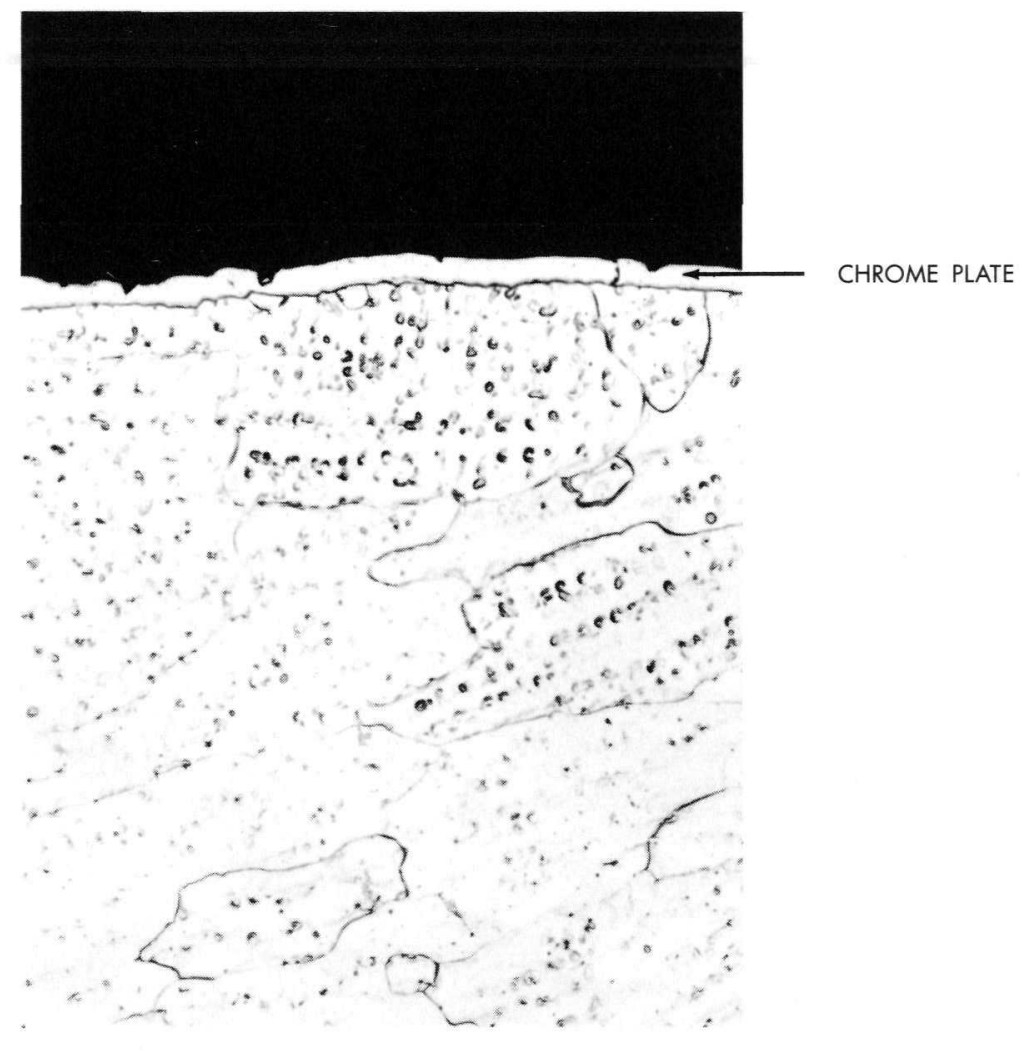

WELD METAL

Figure 2. TIG welded Ni-o-nel exposed to $4 M \mathrm{H}_{2} \mathrm{SO}_{4}$. Transverse section $-250 \times$. Corrosion rate -14 mils per year - 240 hour exposure. 


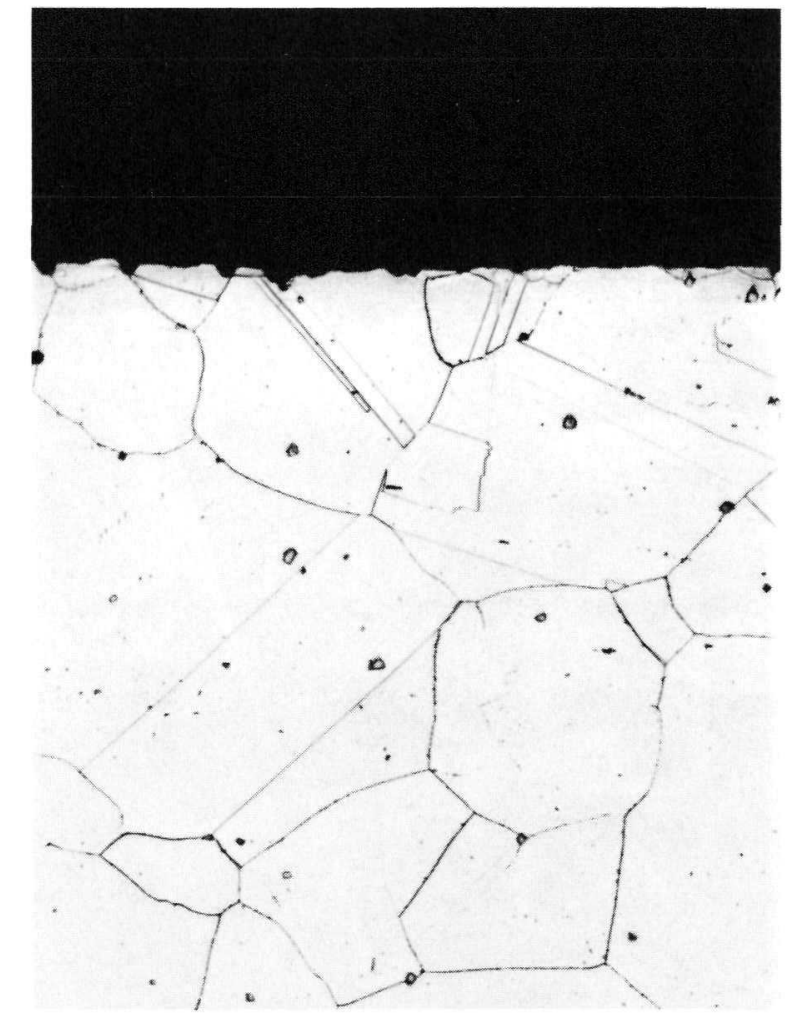

BASE METAL

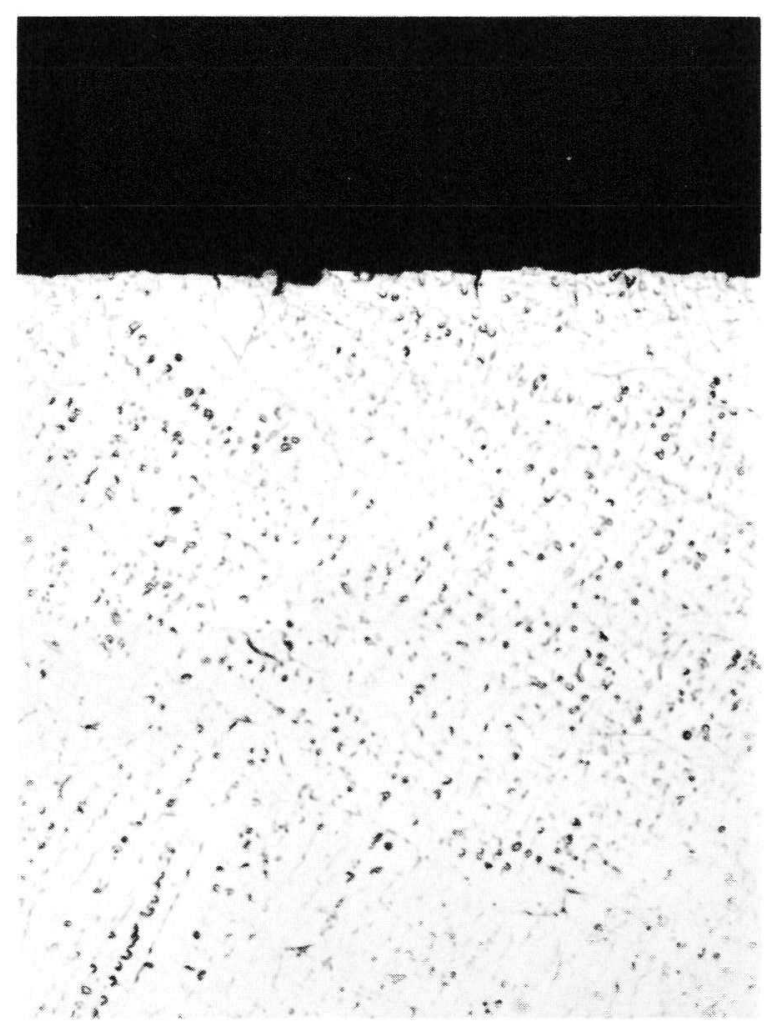

WELD METAL

Figure 3. TIG welded Ni-o-nel exposed to $4 M \mathrm{H}_{2} \mathrm{SO}_{4}+$ $25 \mathrm{~g} / \mathrm{l}$ dissolved stainless steel. Transverse sections $250 \times$. Corrosion rate -8.4 mils per year -240 hour exposure. 


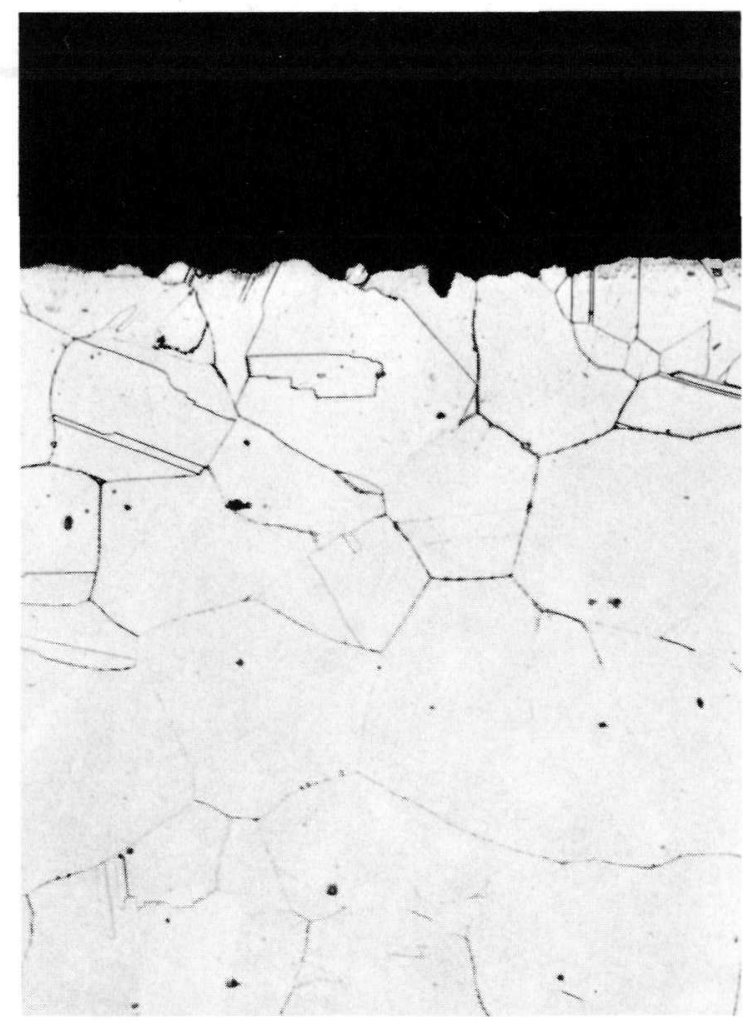

BASE METAL

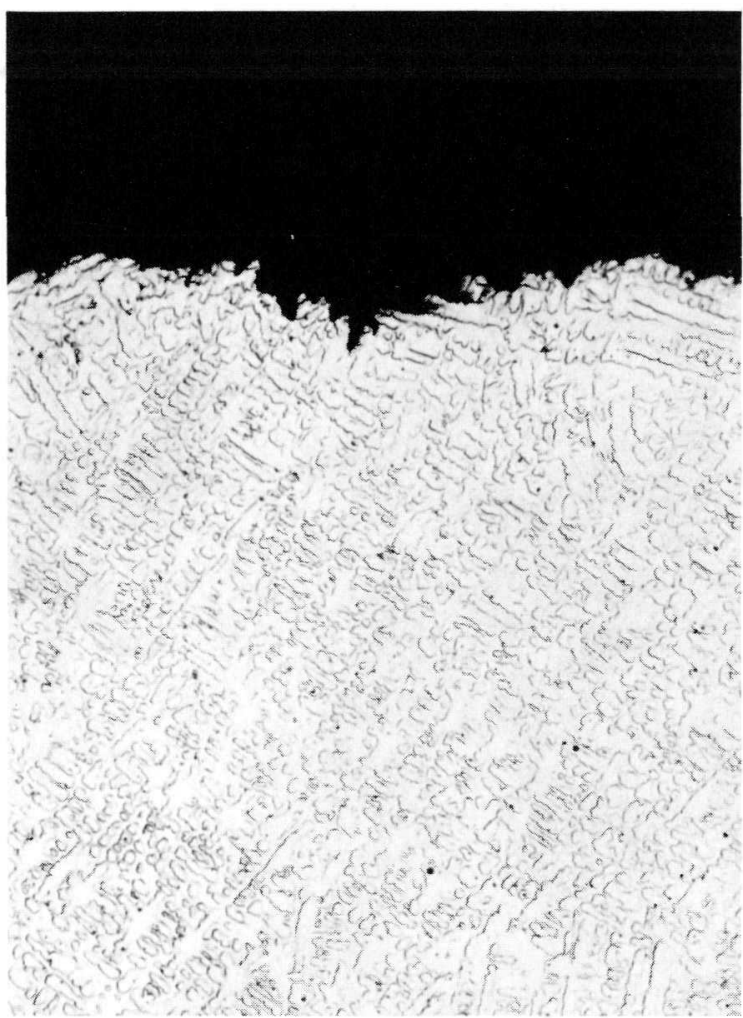

WELD METAL

Figure 4. Metal arc welded Ni-o-nel exposed to $4 M$ $\mathrm{H}_{2} \mathrm{SO}_{4}+25 \mathrm{~g} / 1$ dissolved stainless steel. Transverse sections $-250 \times$. Corrosion rate -20.7 mils per year 240 hour exposure. 


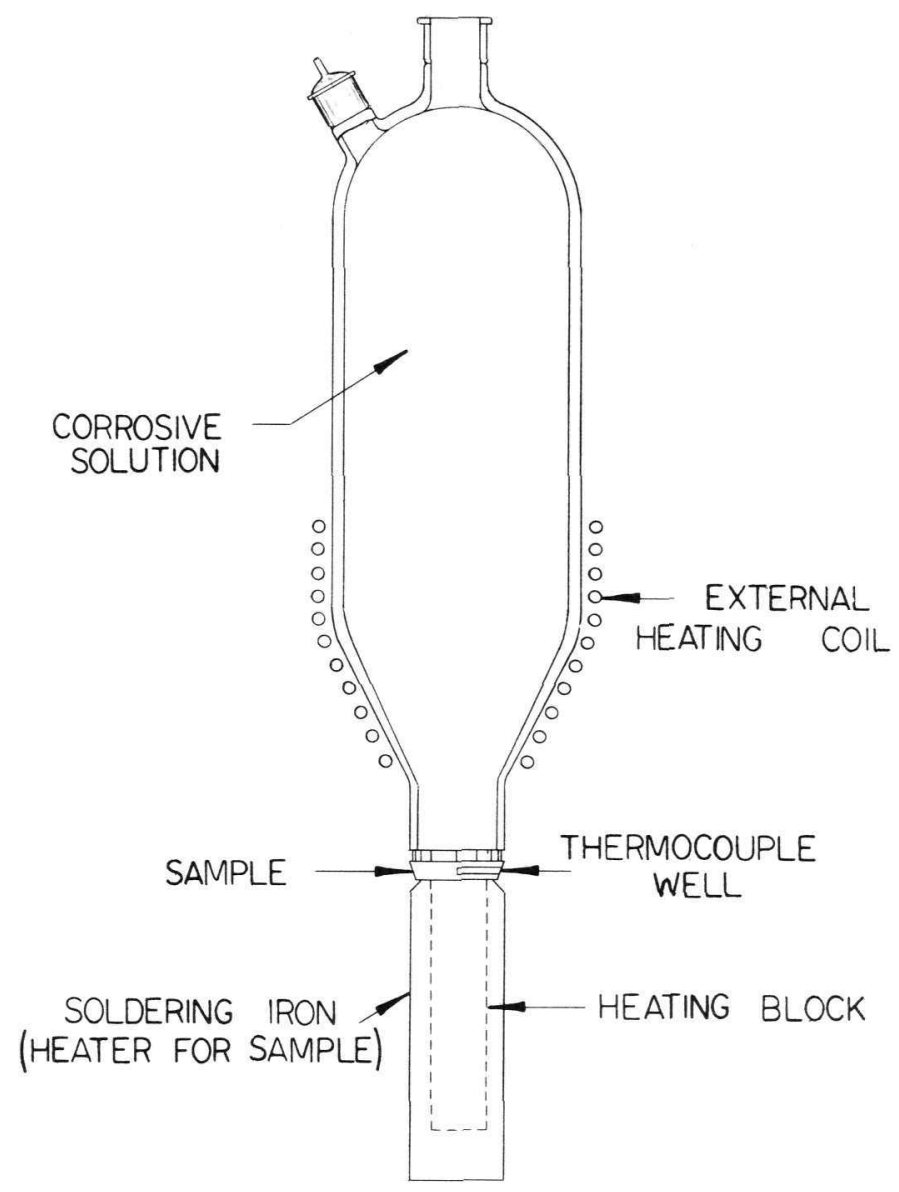

Figure 5. Heat transfer corrosion test apparatus. 


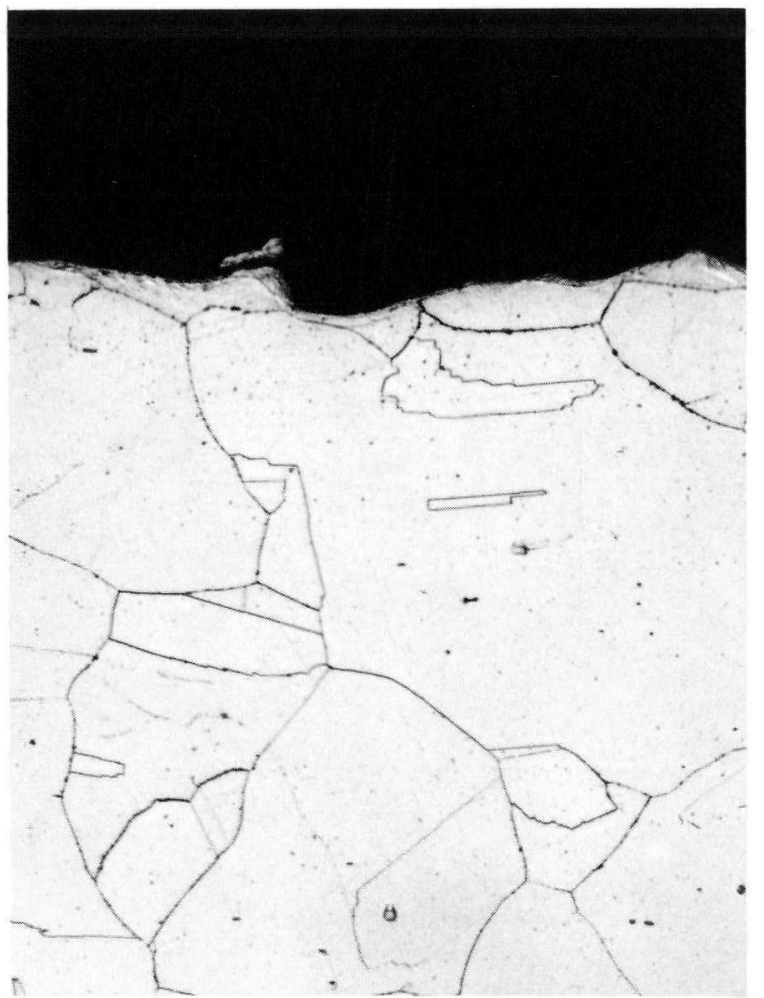

BASE METAL

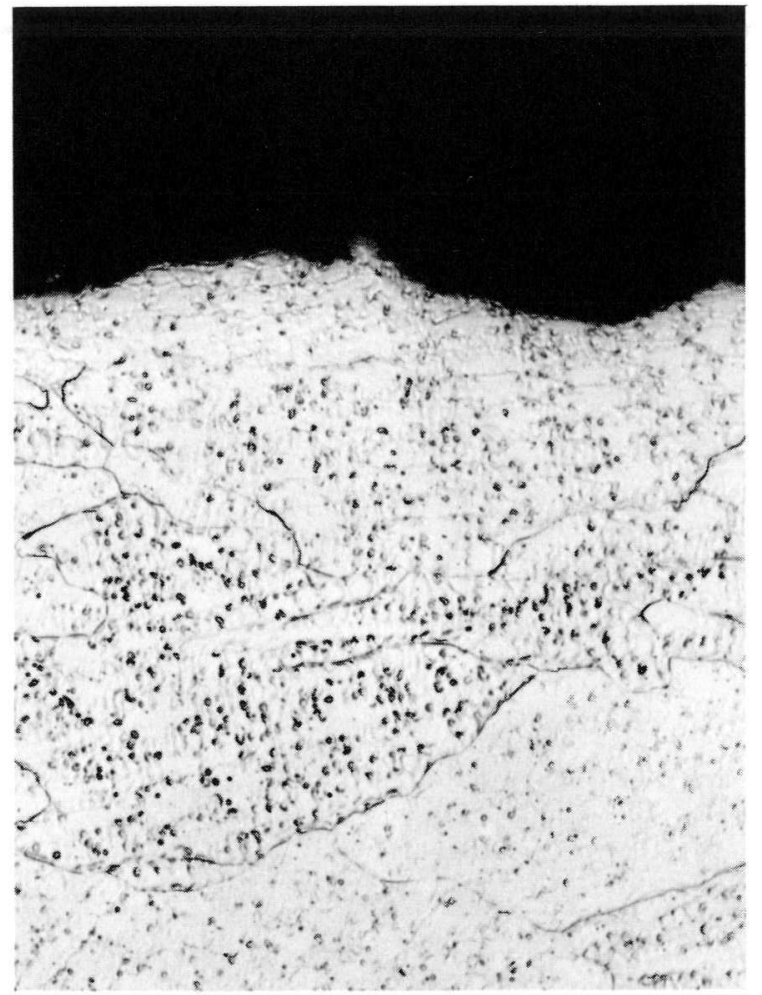

WELD METAL

Figure 6. TIG welded Ni-o-nel exposed to $4 M \mathrm{HNO}_{3}+$ heel. Transverse section $-250 \times$. Corrosion rate -0.9 mils per year - 240 hour exposure. 


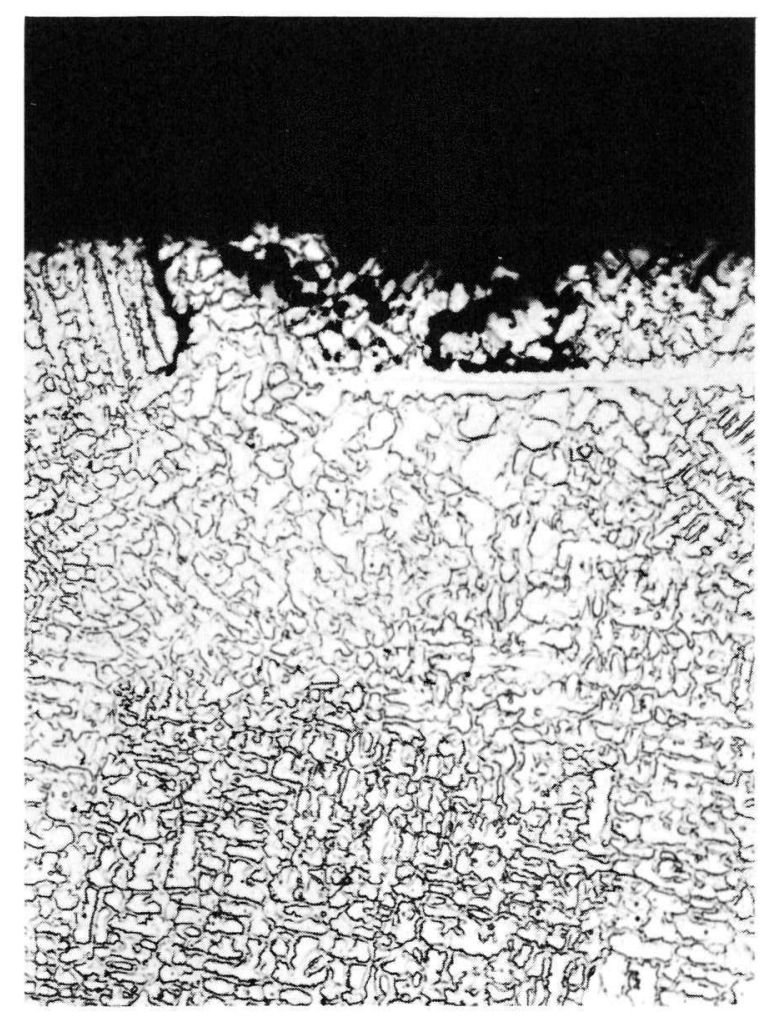

WELD METAL

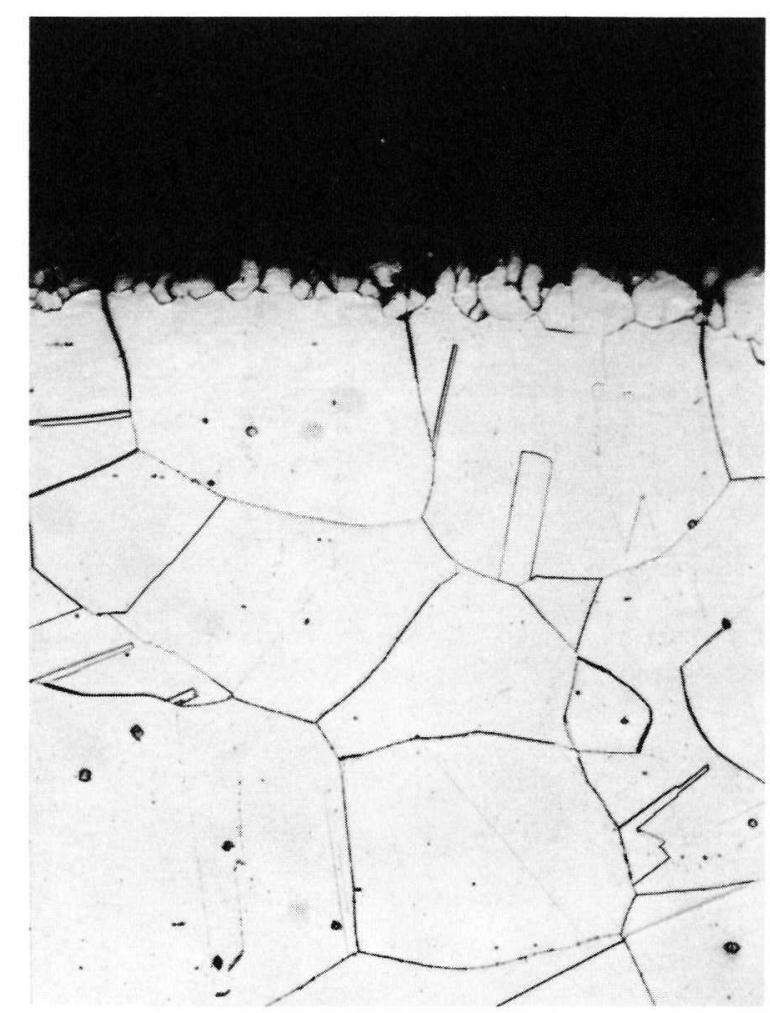

HEAT AFFECTED ZONE

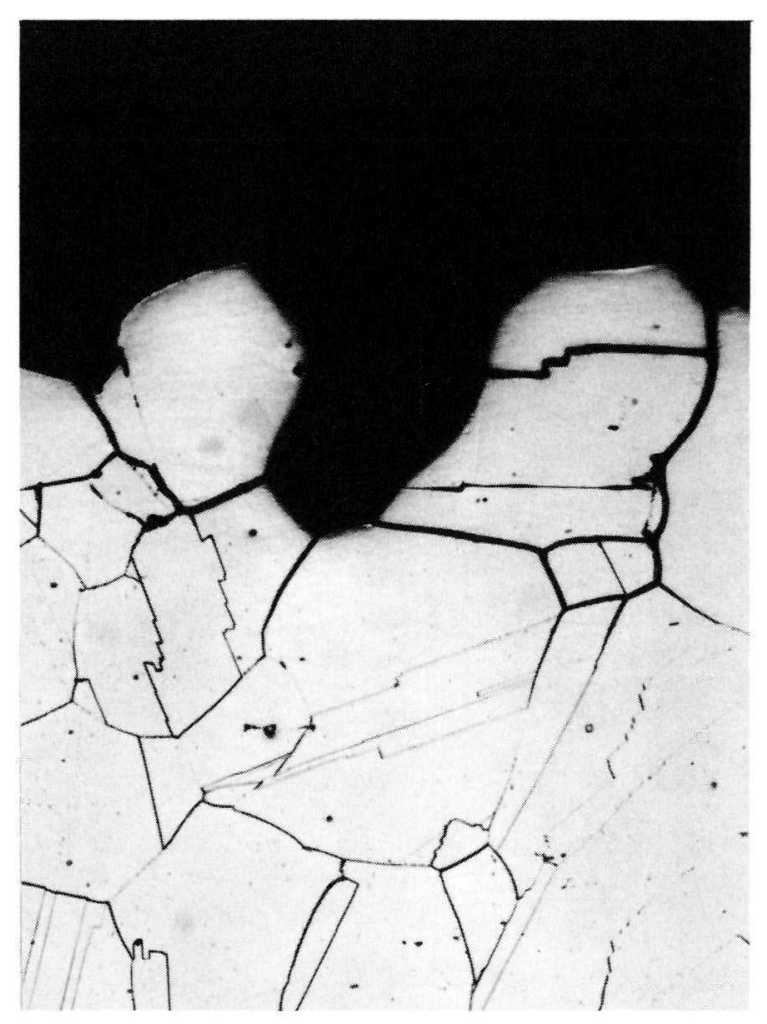

BASE METAL

Figure 7. Metal arc welded Ni-o-nel exposed to $10 \mathrm{M}$ $\mathrm{HNO}_{3}$ vapor phase. Transverse sections $-250 \times .240$ hour exposure. 


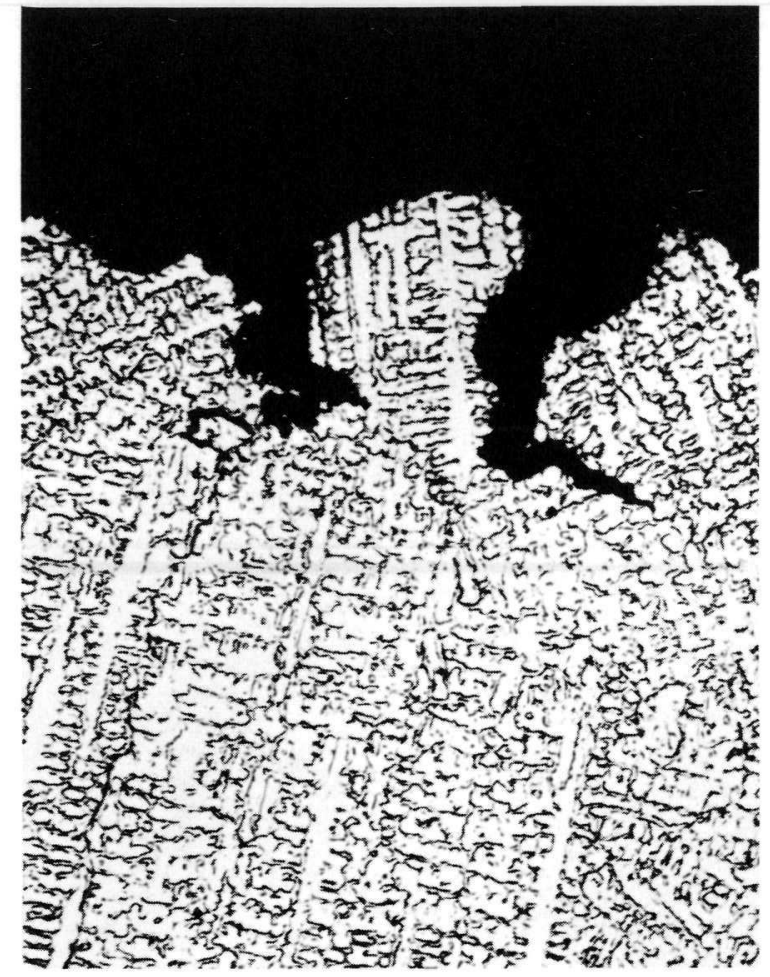

WELD METAL

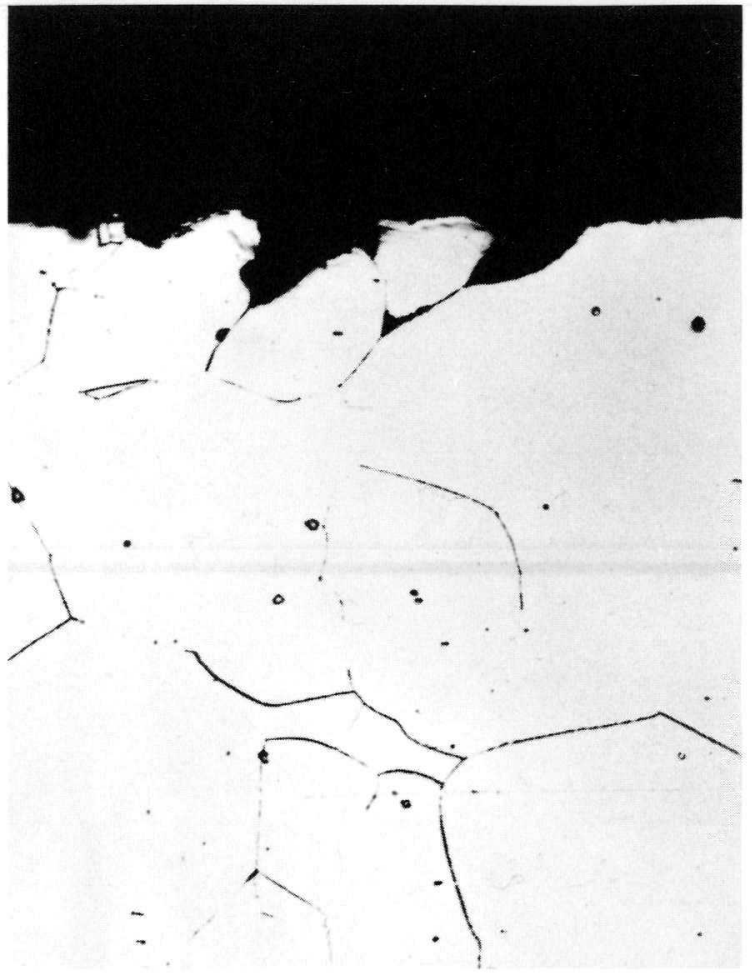

HEAT AFFECTED ZONE

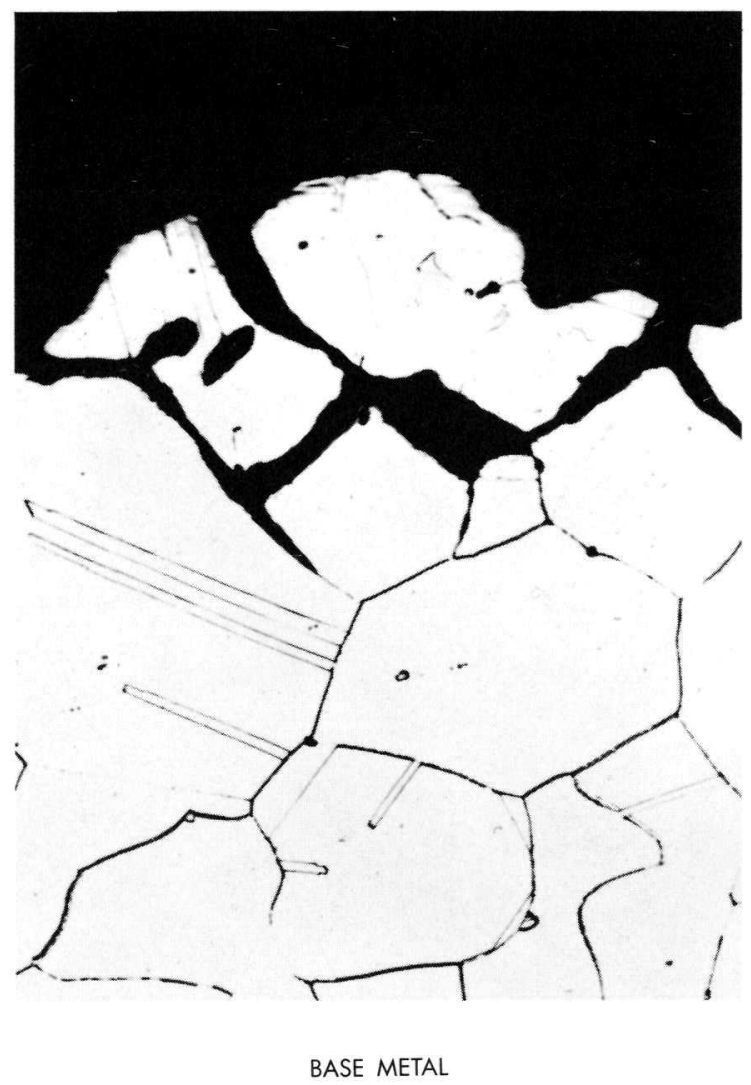

Figure 8. TIG welded Ni-o-nel exposed Zirflex solution + $0.1 M \mathrm{Cu}\left(\mathrm{NO}_{3}\right)_{2}$. Transverse sections $250 \times .120$ hour exposure. 